University of Wollongong

Research Online

2015

Local Governance, Corruption and Public Service Quality: Evidence from a national survey in Viet Nam

Thang Nguyen

Thang Bach

Thanh Le

University of Wollongong, thanhl@uow.edu.au

Canh Le

Follow this and additional works at: https://ro.uow.edu.au/balpapers

Research Online is the open access institutional repository for the University of Wollongong. For further information contact the UOW Library: research-pubs@uow.edu.au 


\title{
Local Governance, Corruption and Public Service Quality: Evidence from a national survey in Viet Nam
}

\author{
Abstract \\ Experiences of developed countries have shown that transparency, accountability, and participation \\ significantly reduce corruption, which in turn helps increase access to and improve the quality of public \\ services. When it comes to developing countries, the links between governance, corruption, and public \\ service quality are under debate. In particular, corruption is widespread in developing countries, and \\ combating corruption in these countries are particularly challenging. In Vietnam, despites the government \\ effort, corruption remains prevalent in the last decade, as international and national indexes have \\ indicated. There is a concern that conventional anti-corruption strategies that focus on promoting \\ transparency, accountability, and participation has failed to achieve satisfactory results at the nationally \\ aggregated level. The main argument is that such strategies require sufficient resources and capable \\ government officials which are lacking in the country. There is also a belief that under complex \\ administrative system and ineffective formal institutions, some corruption may help "greasing the \\ wheels", thereby promoting efficiency. This research focused on corruption at the local level and its effect \\ on public healthcare and public primary education.
}

\section{Keywords}

service, quality:, evidence, national, survey, local, governance, viet, corruption, nam, public

\section{Publication Details}

Nguyen, T., Bach, T., Le, T. \& Le, C. (2015). Local Governance, Corruption and Public Service Quality: Evidence from a national survey in Viet Nam. Ha Noi, Viet Nam: Asia-Pacific Institute for Management (the National Economics University) and the United Nations Development Programme (UNDP) in Viet Nam. 


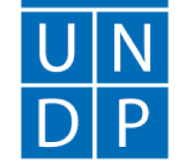

Empowered lives. Resilient nations.

Public Administration Reform and Anti-Corruption A Series of Policy Discussion Papers

\section{Local governance, corruption, and public service quality: Evidence from a national survey in Vietnam}


The series of Policy Discussion Papers on Public Administration Reform and Anti-Corruption is led and edited by Dr Sarah Dix, Policy Advisor on Public Administration Reform and Anti-Corruption at UNDP Viet Nam with substantive support from Ms Do Thanh Huyen, Policy Analyst on Public Administration Reform and AntiCorruption at UNDP Viet Nam.

The series aims to analyze trends in Viet Nam regarding the implementation processes and options in specific public administration reform areas. In order to confront the social, economic, political and environmental challenges facing Viet Nam, policy makers need to be informed by evidence. These policy papers aim to contribute to current policy debate by providing discussion inputs on policy reforms thereby helping to improve Viet Nam's development efforts.

Three principles guide the production of the policy discussion papers: (i) evidence-based research, (ii) academic rigour and independence of analysis, and (iii) social legitimacy and a participatory process. This involves a substantive research approach with a rigorous and systematic identification of policy options on key public administration reform and anti-corruption issues.

Citation: Nguyen Van Thang, Bach Ngoc Thang, Le Quang Thanh and Le Quang Canh (2015). Local Governance, Corruption and Public Service Quality: Evidence from a national survey in Viet Nam. A Joint Policy Research Paper on Governance and Participation commissioned by Asia-Pacific Institute for Management (the National Economics University) and the United Nations Development Programme (UNDP) in Viet Nam. Ha Noi, Viet Nam: December 2015

All rights reserved. No part of this publication may be reproduced, stored in a retrieval system or transmitted, in any form or by any means, electronic, mechanical, photocopying, recording or otherwise without prior permission.

Disclaimer: The views expressed in this policy research paper do not necessarily reflect the official position of the United Nations Development Programme (UNDP).

UNDP Viet Nam

$304 \mathrm{Kim} \mathrm{Ma}$,

Ba Dinh

Ha Noi - Viet Nam

Tel : +84 438500100

fax :+84 437265520

Empowered lives. Resilient nations.
Asia Pacific Institute of Management

(National Economics University)

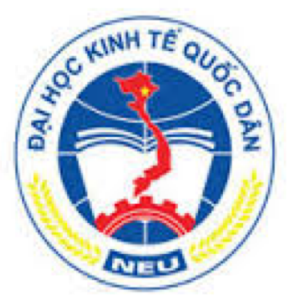




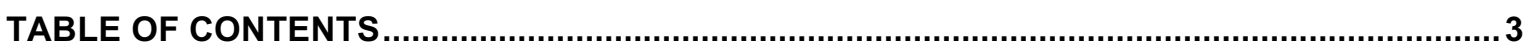

EXECUTIVE SUMMARY AND POLICY RECOMMENDATIONS ................................................. III

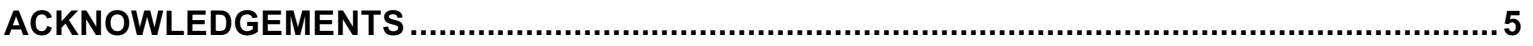

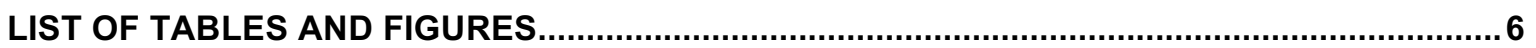

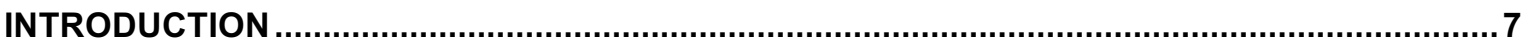

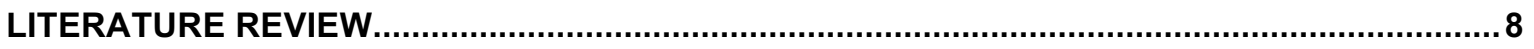

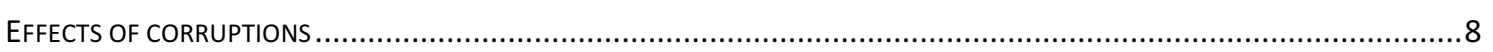

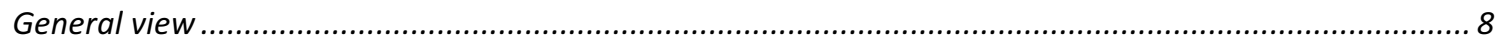

Debate on impacts of corruptions in developing countries.......................................................... 9

ROLE OF TRANSPARENCY, ACCOUNTABILITY AND CITIZEN PARTICIPATION IN ANTI-CORRUPTION ....................................10

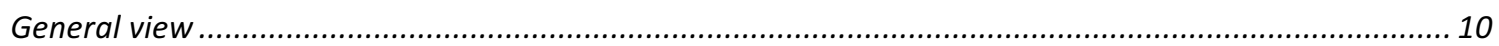

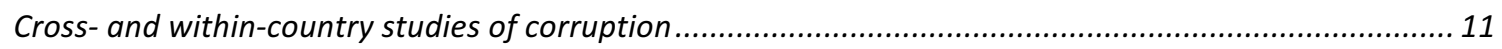

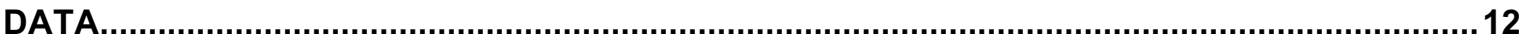

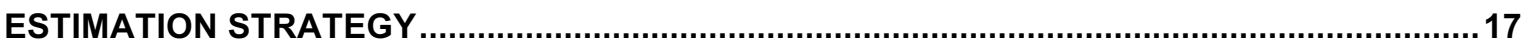

THE MODEL FOR EXAMINING THE EFFECTS OF CITIZEN PARTICIPATION, TRANSPARENCY, AND ACCOUNTABILITY ON

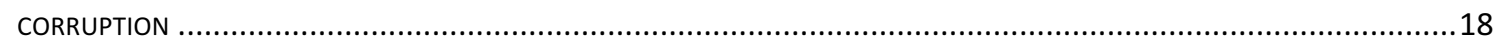

THE MODEL FOR EXAMINING THE EFFECTS OF CORRUPTION ON THE QUALITY OF PUBLIC SERVICE DELIVERY ........................20

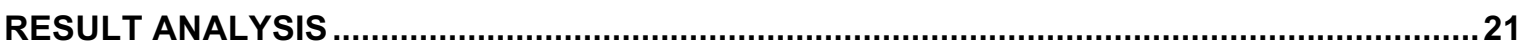

EFFECTS OF CITIZEN TRANSPARENCY, ACCOUNTABILITY, AND PARTICIPATION ON CORRUPTION .....................................2

EFFECTS OF CORRUPTION ON THE QUALITY OF PUBLIC HEALTH CARE AND PRIMARY EDUCATION.....................................22

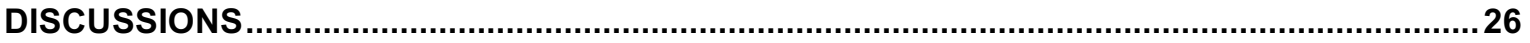

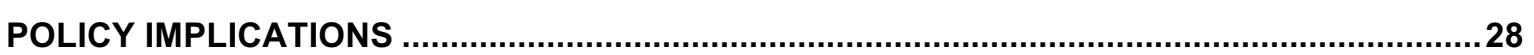

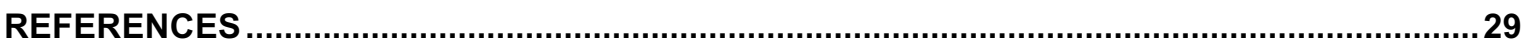

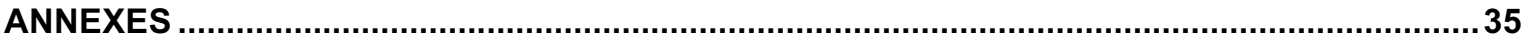




\section{Executive Summary and Policy Recommendations}

Experiences of developed countries have shown that transparency, accountability, and participation significantly reduce corruption, which in turn helps increase access to and improve the quality of public services. When it comes to developing countries, the links between governance, corruption, and public service quality are under debate.

In particular, corruption is widespread in developing countries, and combating corruption in these countries are particularly challenging. In Vietnam, despites the government effort, corruption remains prevalent in the last decade, as international and national indexes have indicated. There is a concern that conventional anti-corruption strategies that focus on promoting transparency, accountability, and participation has failed to achieve satisfactory results at the nationally aggregated level. The main argument is that such strategies require sufficient resources and capable government officials which are lacking in the country. There is also a belief that under complex administrative system and ineffective formal institutions, some corruption may help "greasing the wheels", thereby promoting efficiency.

This research focused on corruption at the local level and its effect on public healthcare and public primary education. We asked two questions in this research:

1) How do citizen participation, transparency, and accountability help reduce corruption?

2) To what extent does corruption affect quality of healthcare and primary education?

Addressing these questions is particularly pertinent as in 2016 the Communist Party of Viet Nam will hold its national Congress and the National Assembly will have elections for a new period $(2016$ - 2020). The results could provide evidences for the Party, the National Assembly, and the Government to sustain the will and revise strategies in combating corruptions. We used annual data from the Viet Nam Provincial Governance and Public Administration Performance Index (PAPI) surveys from 2011 to 2014 to answer the questions.

Our results reject the idea that, in the absence of efficient institutions and administrative systems, corruption can facilitate development. We found that corruption reduces quality of primary education and healthcare, and that effect is consistent over years. This implies that Vietnam cannot wait for higher development before it can combat corruption effectively. Instead, combating corruption is imperative for sustainable development.

Our results also show that transparency, accountability, and citizen participation help reduce corruption, despite existing complex administrative systems. The government commitment in fostering good governance principles is critical for anti-corruption success.

Our study offers several recommendations for consideration in government policy making to enhance local governance and to reduce corruption. These suggestions speak to the key attributing factors under discussion of this research paper: citizen participation, transparency and vertical accountability.

First, active citizen participation in local political life through transparent and fair elections of village heads is critical. So is it for citizen engagement in reporting corruption however petty the corruption practices is. Promoting citizen activism in the political context of Viet Nam requires the openness and proactiveness of both sides of the coin: the citizenry and the government. With a more rights-based constitutional foundation set forth in the 2013 Constitution, together with the support of new technology and more open media, there is light of hopes for greater genuine citizen participation for better governance in Viet Nam in the years to come.

Second, genuine participation is hard to obtain in anti-corruption agendas when citizens are not encouraged to report against any wrong doings by public officials and when they feel they are not protected when taking anticorruption initiatives. As our research has shown, citizens' willingness to report corrupt practices decreased in the period from 20112014. Promoting the roles of media and civil 
society to be the intermediary platforms for citizens to report on corruption will help central and local governments to prevent corruption. Upcoming revisions to anti-corruption legislations should spell this out more profoundly so as to improve the effectiveness of anti-corruption work in Viet Nam.

Third, citizen participation and the accountability mechanism like People's Inspection Boards would be meaningless if transparency is not respected. In the last decade, the need for more transparency and information disclosure has been well recognized. However, the relevance (i.e. the level of details and disaggregation of data) and quality (i.e. the reliability and timeliness) of information needs to be improved. In an essence, disclosure of budget and expenditure information helps reduce corruption at local levels while more access to other types of government information would be necessary to enhance anti-corruption effectiveness. It is timely for a Law on Access to Information that facilitates rather than policing access to information to be promulgated. The law will serve as a legal framework to foster transparency and engage citizens and institutions in calling central and local governments into account and keeping public service delivery agencies under check to better control corruption. In addition, building strong databases in important areas, such as a land registrar system and an open budget system for both central and local governments, would be critical in promoting citizen access to information.

Third, accountability to citizens and non-state actors need to be fostered among public officials and civil servants. As the research and UNDP, CECDES and VFF (2014) have pointed out, it is important to improve the effectiveness of the People's Inspection Boards, the grassroots monitoring mechanisms by citizens to keep the performance of public officials and civil servants under check. By giving PIBs enlarging space, necessary skills and easy-tofollow toolkits, these boards will exercise their mandates and power as promulgated in the Ordinance on Grassroots Democracy and the Law on Inspection. In order for PIBs to be effective, citizen participation in selection of their members is a must.
Last but not the least, fostering good governance means that the government needs to gain a considerable trust from the public. To this end, there should be a fundamental shift in the mindset and attitude of public officials. Providing good information to the public, inviting the public to participate in policy agenda, and responding accountably to the public concerns are good mechanisms to gain trust and fight corruption. 


\section{Acknowledgements}

The authors thank Sarah Dix (UNDP), Do Thanh Huyen (UNDP), and Edmund Malesky (Duke University, USA) and participants of the UNDP's thematic discussion 'Anti-corruption for Social Equality in Viet Nam' on the $9^{\text {th }}$ of December 2015 for valuable comments and suggestions to an earlier draft of the paper. Financial support from UNDP is acknowledged.

The contents and analysis of the report, along with any errors in interpretation, rest entirely with the authors. 


\section{List of tables and figures}

Table 1: Measures of the variables $\quad 12$

Table 2: Overall corruption perception and some governance attributes $\quad 13$

Table 3: Effects of transparency, accountability and participation on corruption 21

Table 4: Corruption and the quality of health care $\quad 24$

Table 5: Corruption and the quality of primary education 26

$\begin{array}{ll}\text { Figure 1: Perception of six corruption practices } & 14\end{array}$

Figure 2: Corruption, quality of public service delivery, and some other aggregates at the district level 
Corruption is widely seen as an obstacle for a country development (Kaufmann, 2005). At the national level, corruption deters investment, inhibits innovation, and slows down economic growth (Kaufmann, 2005; Lou, 2002). When it comes to developing countries, there still a debate on whether corruption has any positive impact on development. A number of studies have found that corruption entrenches hunger and poverty, inhibits innovation, and triggers social instability (Otusanya, 2011; Nguyen, Ho, Le, \& Nguyen, 2016). On the other hand, recent empirical evidence supporting the "greasing the wheels" hypothesis does exist (e.g., (Dreher \& Gassebner, 2013; Meon \& Sekkat, 2005; Meon \& Weill, 2010; Vial \& Hanoteau, 2010). Most of these evidences were discovered in economic sectors, such as firm entry, efficiency, or productivity. Whether the "greasing the wheels" hypothesis works for socially-intense public services, such as healthcare and education, remains unanswered. It is pertinent to collect more empirical evidence to inform the debate on this issue.

Generic anti-corruption strategies often call for transparency, accountability, and participation (hereafter, TA\&P) (Kaufmann, 2005). The TA\&P attributes are believed to reduce officials' discretion, increase community monitoring, and set a solid foundation for a proper punishment of corrupted acts (Khan, 2006). The implementation of these strategies, however, requires a strong rule compliance behavior and an adequate law enforcement capacity (Hors, 2000; Khan, 2006), which often are lacking in developing countries (Garcia-Zamor, 2015; Samaratunge \& Wijewardena, 2009). In addition, the real driver of corruption in developing countries is not necessarily discretion of officials but rather rule-violating behaviour of the related parties (Khan, 2006). Thus, TA\&P strategies may not be effective in reducing at least some types of corruption in developing countries (Khan, 2006; Spector, 2005). The debate continues as strong empirical evidence, especially at the sectorial level, in developing countries is rare.

To address these gaps, we asked two questions in this study: i) How do citizen participation, transparency, and accountability help reduce corruption? and ii) To what extent does corruption affect quality of public healthcare and primary education? We utilized a national citizen survey in Vietnam to answer these questions. Vietnam is an ideal setting for studying the relationships between TA\&P, corruption, and public service quality. The country's dual ideology (i.e., market economy under socialist direction) and ambivalent reform direction offers a unique natural laboratory on the dilemma between promoting TA\&P and maintaining traditional bureaucratic state management (Painter, 2008; Nguyen et al., 2015). The current trend of marketization and removal of public welfare has been rooted in the shortage of the state budget, rather than in modern public management principles (APIM, 2014). This has created a high potential for corruption and quality problems in the delivery of public services (Painter, 2008). Thus, studying the links between TA\&P, corruption, and public service quality in this country is practically pertinent and theoretically meaningful.

We use the annual Viet Nam Provincial Governance and Public Administration Performance Index (PAPI) data from 2011 to 2014 to answer the questions. The data at the individual level allows us to reliably demonstrate the relationship between local TA\&P and corruption. The panel districtaggregated data allows us to examine the interplay between corruption and the quality of public service delivery, while controlling for the influence of local conditions. As discussed, the links between TA\&P, corruption and public service quality in developing countries has been under debate, and thus, our systematic enquiry of these issues is a contribution to the literature.

The next section briefly reviews the literature on corruption, its impact on access to quality public services, and anti-corruption strategies with special attention to TA\&P. Data, empirical strategies and results are then presented. The study concludes with a discussion of the findings. 


\section{Literature Review}

\section{Effects of corruptions}

\section{General view}

Corruption has been considered to be a major problem in human societies throughout time and space. Corruption scandals have been found not only in developing countries (e.g. China, India, Nigeria, Vietnam) but also in developed nations (e.g. France, the United Kingdom, the United States) (Dong, 2011). While corruption may benefit a smaller number of people holding public offices, it hurts the society as a whole because corruption causes harmful effects on economic development and social welfare (Kaufmann, 1997). The harmful effects of corruption have been documented in a number of studies. Specifically, there exists evidence that corruption reduces the incentive of making private investment (Bardhan, 1997), distorts public investment decisions (Tanzi and Davoodi, 1997; Mauro, 1998) and erodes integrity values (Murphy et al, 1991; 1993). Wei (2000) and Fredriksson et al. (2003) reveal that corruption lowers foreign direct investment (FDI) as it implies a higher expropriation risk.

In basic areas such as education and health, corruption is found to weaken the provision of these public services. According to Giedon et al. (2001) (as cited in Azfar and Gurgur, 2008), corruption in the health sector occurs alongside three categories of relationship: between doctors and patients; between hospitals and payers; and between hospitals and suppliers. In the doctorpatient relationship, corruption acts include a doctor's improper use of public facilities for private practice or his/her absence or negligence during duty hours to increase demand for private practice. In the hospital-payer relationship, a false bill may be produced. In the latter relationship, corruption may take the form of bribery for awarding a contract.

In any case, corruption leads to higher costs for consumers and, hence, dampens demand for health services and may even result in a worse health outcome. It also raises operating costs for the government and makes fewer resources available for health services (Azfar and Gurgur, 2008). In particular, Azfar and Gurgur (2008) find that corruption reduces immunization rates, delays vaccination in newborns and lengthens the time of waiting at public hospitals in the Philippines. It also enlarges the difference in accessibility to health services between urban and rural areas and between the rich and the poor.

Corruption in education occurs at different scales, ranging from national education ministries to universities or schools. Examples include bribes paid to teachers by parents, bribes paid to public officials by teachers to get preferred positions or promotion, bribes paid to teachers for lowering passing criteria, selling exam information and selling degrees, among others (Khan et al., 2015; Nguyen, 2007; Transparency International, 2015; Truex, 2011).

Corruption in education is often considered to be highly damaging due to its long term effects on people's lives (Khan et al., 2015; Nguyen, 2007; Transparency International, 2015; Truex, 2007). Through time, corruption in education erodes all the social, economic and political values of the society by destroying personal integrity. Because education often takes up to 20-30 percent of a government's budget, this sector is highly prone to corruption (Khan et al., 2015; Nguyen, 2007; Transparency International, 2015). Under the effect of corruption, equal access to quality education is no longer guaranteed. The consequence is found to be harsher for the poor as they will be more likely to be trapped in poverty if they have low quality education. More severely, young generations lose their confidence in the society leading to a serious breakdown of social trust. Crimes and social vices will then develop. 


\section{Debate on impacts of corruptions in developing countries}

Generally speaking, corruption is more severe in developing countries than in their developed counterparts (Tanzi, 1998). According to Fisman and Gatti (2002a), developing countries are often found to have excessive government interventions and discretionary spending and an under-performing taxation system which contains high tax rates in concurrent with loopholes and nontransparent procedures. The law enforcement in these countries is often found weak. In addition, monitoring by non-state actors is usually in a nascent stage. These are the main factors that nourish pervasive corruption in the countries.

Whether corruption has any positive effect in developing countries is still under debate. On the one hand, corruption is generally found to harm overall development as it reduces the incentives for entrepreneurs to make private investment and distorts public investment. Apart from the stolen revenue (e.g., tax evasion and avoidance), corruption erodes integrity and promotes misallocation of resources (Hors, 2000; Kaufmann, 1997). Otusanya (2011) conducted a thorough literature review and found that most of the studies found harmful effect of corruption. Instead of investing in health, education and infrastructure to pave the way for private investment, public investment is made in undesirable directions that reduce the quality of that public spending (see Otusanya, 2011 for a review). Similarly, Welsch (2004), Pellegrini \& Gerlagh (2006) find that corruption exacerbates pollution in several developing countries. ${ }^{1}$

On the other hand, in the absence of effective administrative system and capable public servants, corruption is believed to create some positive impact for a country's development (Meon and Sekkat, 2005; Meon and Weill, 2010). The "greasing the wheels" hypothesis was proposed prominently in the 1960s (namely Leff, 1964; Leys, 1965), and remains under debate. Meon and Sekkat (2005) summarized the arguments supporting this hypothesis. First, corruption can speed up bureaucratic procedures. Bribes are incentives for officials to respond more quickly to citizens' requests. Second, grafts and bribes can serve as supplement income for low wage in government jobs. The paper argues that the additional incentive helps attract capable candidates which then results in better services. Finally, resources and licenses can be allocated more efficiently as the most efficient firms can pay the highest bribes.

Recent empirical evidence for "greasing the wheels" does exist, albeit less popular than those for negative impact of corruption. For example, Meon and Weill (2010) found that corruption reduce aggregate efficiency in countries where institutions are effective, yet increases efficiency where institutions are ineffective. Dreher and Gassebner (2013) studied whether corruption reduces the negative impact of regulation on entrepreneurship in highly regulated economies in 43 countries over the $2003-2005$ period. The authors found that corruption facilitates firm entry in highly regulated economies, supporting "greasing the wheels" hypothesis. In a similar vein, Vial and Hanoteau (2010) assessed the impact of plant-level corruption on output and productivity growth, using panel data from Indonesian manufacturing industry during the Suharto era (1975 - 1995). The authors found that corruption, measured as bribes and indirect tax payment, has a positive effect on individual plant growth.

Note that almost all empirical evidences supporting the "greasing the wheels" hypothesis were found in the context of underdeveloped institutions, highly regulated and extremely bureaucratic

\footnotetext{
${ }^{1}$ According to Lui (1985), in an already distorted economy, bribery may increase the overall efficiency of that system by greasing the wheel. In a counter-argument, Rose-Ackerman (1999) indicates that the effect does not apply to issues such as tax evasion, violation of environmental law or recruitment of disqualified people into public offices. Bureaucrats also tend to delay their work in order to increase their chance of obtaining more private gains.
} 
systems. The positive effects of corruption were found either at micro (firm or even plant) level or in purely short-term economic efficiency. The impact of corruption on blocking the reform of such inefficient institutions and systems has never been discussed in these studies. In addition, most of the evidence supporting the "greasing the wheels" hypothesis was found in the economic sector. Whether this hypothesis works in socially-intensive public services, such as healthcare and education, remains unknown. Moreover, the impact of "greasing" on equity is largely ignored. Most of the positive effect of corruption is for the rich or companies who can afford the bribes.

We argue that most of corruption positive effect are transaction-specific and short-term. In comparison, its overall and long-term impact on blocking institutional reform, eroding innovation and integrity is much more damaging to the country (Nguyen et al., 2016). This is especially true for public services, such as healthcare and education, where staff morality is an integral part of the service quality. Therefore, we hypothesize:

H1: Corruption has a negative relationship with service quality in a) healthcare, and b) education.

\section{Role of transparency, accountability and citizen participation in anti-corruption}

\section{General view}

In order to enhance the economic efficiency of investment activities and reduce corruption, it is required to have transparent mechanisms and procedures of policy making in public offices and make government officials accountable for their decisions. As pointed out by Brinkerhoff (2004), accountability consists of three key components: measurement of goals and results; justifications of those goals and results to monitoring organizations or other factors; and punishments in case of non-performance or corrupt acts. Hence, accountability will be greatly improved if things are made clear on how inputs are used to produce outputs and there exist monitoring organizations and opportunities for other actors to keep close watch on the process. Different incentive and punishment schemes should also be in place to reward good performance and penalize poor performance (Vian, 2007). Along with accountability is the transparency of information. This requires the disclosure of government documents or decisions through public meetings or media and information on how performance is measured. Transparency helps strengthen accountability and inform citizens of choice (Vian, 2007).

In combating corruption, citizen participation is as the functioning of formal institutions because it reflects citizens' attitudes towards such acts (Wells-Dang, Le, and Nguyen, 2015). Given that citizens play an important role as watchdogs of officials' behaviors, transparency and accountability cannot be efficiently maintained without citizens taking an active stance on rejecting and reporting corruption. It is found that people's propensity to reject or report corruption varies across individuals depending on their background of education (Truex, 2011; Lavena, 2013), gender (Goetz, 2007), age (Seligson, 2002; Lavena, 2013), and financial well-being (Soares, 2004; Melgar et al., 2010). ${ }^{2}$ Having an insight into these issues will help anti-corruption actors focus their resources on areas where they work best to encourage citizens to join forces with them to address corruption (Walton and Peiffer, 2015).

2 This is cited in Walton and Peiffer (2015). Generally speaking, more educated people tend to deny corruption more often and are more willing to reveal about corruption. Corruption is also found less likely to be tolerated by the older and less well-off people. 


\section{Debates on effectiveness of TA\&P in developing countries}

Scholars have argued that the problem of corruption in developing countries cannot be solved by simply applying anti-corruption structures that work in advanced countries (Hors, 2000; Khan, 2006). Pure TA\&P strategies may not work well at the aggregated level in developing countries for several reasons. First, political corruption is quite spread in developing countries (Khan, 2006). Many politicians owe their career and status to corruption, and few of them, if any, would stand against it (Hors, 2000). For this type of corruption, pure TA\&P will not work since these politicians are the ones who decide how much TA\&P to be applied. Second, there are obstacles for implementation of TA\&P. Most developing countries lack law enforcement experts, capable public officials and the resources for these strategies (Hors, 2000; Salifu, 2008). Finally, the ignorance and silence of victims, maintained by a culture of fear nurtured by those who benefit from corruption, is another impediment to fighting corruption (Hors, 2000).

Fitzsimons (2009) conducted an empirical study on relationships between public sector reform (which resembling TA\&P) and corruption. The author found a significant increase in corruption following public sector reform, with an unusual degree of persistence even after general institutional reforms had been completed. The surprising conclusion is that unenthusiastic reformers may have better control of corruption than those who diligently pursue the recommended policies. Similarly, Vian (2007) found that increasing citizens' voice is not always easy, especially in developing countries. Citizens in these countries often have long been suppressed by corrupt governments and there is often lack of non-governmental organizations and other forms of civic activism.

We argue that the challenges in implementation of TA\&P do not justify bypassing these measures. Moreover, the prevalence of political corruption in many developing countries means that the anticorruption agenda may need to have more focused targets. Following Salifu (2008), we argue that public services (including administrative services) are among sectors that need to apply TA\&P strategies, especially in early stage of country development. These services directly affect citizens' welfare, and thus their involvement is both necessary and possible. We consider that the level of TA\&P would significantly reduce corruption in the provision of these services. Therefore we hypothesize:

H2: The levels of a) Transparency; b) Accountability to citizens; and c) Citizen Participation are negatively related to corruption in local public services.

\section{Cross- and within-country studies of corruption}

Most empirical papers examining the impact of corruption on economic development are crosscountry investigations (e.g. Pellegrini and Gerlagh 2004; Aidt et al, 2008). In conducting their analyses, these papers use datasets spanning a large number of countries over a period of time. While these datasets allow them to study similarities and differences between countries and across time specified in the sample, they are subject to several limitations such as subjective bias and omitted variable bias (unobservable differences in cultures or institutions).

To overcome these limitations, there has been more interest in studying the socio-economic effects of corruption using within country data, in recent years. The key advantage of withincountry data is that it helps eliminate the subjective data bias due to background characteristics. However, the majority of these studies either employ data on the US (e.g. Goel and Nelson, 1998; Fisman and Gatti, 2002b; Campante and Do, 2014) or the Chinese economy (e.g. Cai et al. 2009; Dong, 2011) leaving a few exceptions from other developing countries such as Nepal (e.g. Truex, 2011), the Philippines (e.g. Azfar \& Gurgur, 2008), Papua New Guinea (e.g. Walton, 2015), and Uganda (e.g. Deininger \& Mpuga, 2004). More within-country studies on corruption in developing 
world would contribute to the literature on how corruption work and what measures are effective in such countries. We add to the literature by providing evidence from a within-country study of corruption in Vietnam.

\section{Data}

The data for the empirical analysis is drawn from the Vietnam Provincial Governance and Public Administration Performance Index (the PAPI) (UNDP, VFF \& CECODES, 2014). This is an annual large-scale survey of citizens' experiences in the three mutually reinforcing processes across provinces in Vietnam: (i) policy making, (ii) policy implementation, and (iii) the monitoring of public service delivery. Its sampling method is probability proportion to size (PPS) to which the selection of districts, communes/wards, and villages/groups is randomized. Therefore, the chance of getting included in the survey is dependent on the population proportions of those geographical observations. Since 2011 the survey has been conducted in all of the 63 provinces in Vietnam. It targets annually some 207 districts, 414 communes/wards, and 828 villages/groups. Each year about 14,000 people/individuals, aged from 18 and above, are randomly selected for the interviews by the questionnaire-based survey method. ${ }^{3}$

The measures for our models are summarized in Table $1 .{ }^{4}$

Table 1: Measures of the variables

\begin{tabular}{|c|c|c|}
\hline Variables & Measure & Scale \\
\hline \multicolumn{3}{|l|}{ Corruption } \\
\hline $\begin{array}{l}\text { Overall corruption } \\
\text { perception }^{\text {a }}\end{array}$ & $\begin{array}{l}\text { Overall corruption perception, an additive } \\
\text { number in the six specific measures of } \\
\text { corruption practices, i.e. diversion of state } \\
\text { budget, bribes for land titles, bribes for } \\
\text { health care, bribes for primary education, } \\
\text { bribes for construction permit, and bribes } \\
\text { for state employment. }\end{array}$ & From 0 - 6 \\
\hline $\begin{array}{l}\text { Corruption perception in } \\
\text { health care }\end{array}$ & $\begin{array}{l}\text { Perception of corruption in access to } \\
\text { public health care }\end{array}$ & $\begin{array}{c}\text { Averaged scale from } 0 \text { to } \\
2\end{array}$ \\
\hline $\begin{array}{l}\text { Corruption perception in } \\
\text { primary education }\end{array}$ & $\begin{array}{l}\text { Perception of corruption in access to } \\
\text { primary education }\end{array}$ & $\begin{array}{c}\text { Averaged scale from } 0 \text { to } \\
2\end{array}$ \\
\hline
\end{tabular}

${ }^{3}$ For the detailed description of the PAPI surveys, including the survey method and its content, log onto http://papi.vn/en/faq.html.

${ }^{4}$ Details on all variable description and source of data in the PAPI questionnaire are presented in Table 2 of Appendix 1. 


\begin{tabular}{|c|c|c|}
\hline Variables & Measure & Scale \\
\hline Voting in local election & $\begin{array}{l}\text { Whether citizens come to vote personally } \\
\text { in local elections of village heads or } \\
\text { residential area heads }\end{array}$ & Yes (1), No (0) \\
\hline $\begin{array}{l}\text { Unwillingness to report } \\
\text { corruption }^{\text {b }}\end{array}$ & $\begin{array}{l}\text { The amount of bribe to which citizens do } \\
\text { not mind filing a denunciation to } \\
\text { responsible government authorities }\end{array}$ & $\begin{array}{l}\text { Scale from } 1-10, \\
\text { whereas higher values } \\
\text { reflect lower willingness } \\
\text { to report corruption }\end{array}$ \\
\hline \multicolumn{3}{|l|}{ Transparency } \\
\hline $\begin{array}{l}\text { Commune budget and } \\
\text { expenditure disclosure }\end{array}$ & $\begin{array}{l}\text { Whether commune/ward budget revenue } \\
\text { and expenditures were publicized }\end{array}$ & Yes (1), No (0) \\
\hline \multicolumn{3}{|l|}{ Accountability } \\
\hline $\begin{array}{l}\text { Effectiveness of } \\
\text { People's Inspection } \\
\text { Boards }\end{array}$ & $\begin{array}{l}\text { The extent to which People's Inspection } \\
\text { Boards function effectively }\end{array}$ & Yes (1), No (0) \\
\hline $\begin{array}{l}\text { Seriousness of local } \\
\text { governments in dealing } \\
\text { with corruption cases }\end{array}$ & $\begin{array}{l}\text { Whether provincial governments are } \\
\text { serious about dealing with corruption } \\
\text { cases }\end{array}$ & Yes (1), No (0) \\
\hline \multicolumn{3}{|l|}{ Public service quality: } \\
\hline $\begin{array}{l}\text { Quality of public health } \\
\text { care }\end{array}$ & $\begin{array}{l}\text { Average percentage of citizens valuing } \\
\text { good quality of health care at district public } \\
\text { hospital, in various aspects }\end{array}$ & $\begin{array}{l}\text { Average percentage - } \\
\text { the higher the value, the } \\
\text { better the service quality }\end{array}$ \\
\hline $\begin{array}{l}\text { Quality of public primary } \\
\text { education }\end{array}$ & $\begin{array}{l}\text { Average percentage of citizens valuing } \\
\text { good quality of primary education at public } \\
\text { primary schools, in various aspects }\end{array}$ & $\begin{array}{l}\text { Average percentage - } \\
\text { the higher the value, the } \\
\text { better the service quality }\end{array}$ \\
\hline
\end{tabular}

This section shows the summary statistics of the PAPI data used in the empirical analysis. The data is constructed on the individual-level (Table 2 and Figure 1), and on the district-aggregated level (Figure 2).

Table 2: Overall corruption perception and some governance attributes

\begin{tabular}{|c|c|c|c|c|}
\hline Variables & 2011 & 2012 & 2013 & 2014 \\
\hline Overall corruption perception ${ }^{a}$ & 1.7 & 1.8 & 1.9 & 2.0 \\
\hline Voting in local elections & $72 \%$ & $73 \%$ & $71 \%$ & $67 \%$ \\
\hline Unwillingness to report corruption ${ }^{b}$ & 3.3 & 3.4 & 4.1 & 4.3 \\
\hline $\begin{array}{l}\text { Commune budget and expenditure } \\
\text { disclosure }\end{array}$ & $64 \%$ & $70 \%$ & $71 \%$ & $72 \%$ \\
\hline $\begin{array}{l}\text { Effectiveness of People's Inspection } \\
\text { Boards }\end{array}$ & $52 \%$ & $55 \%$ & $57 \%$ & $58 \%$ \\
\hline $\begin{array}{l}\text { Seriousness of local governments in } \\
\text { dealing with corruption cases }\end{array}$ & $54 \%$ & $53 \%$ & $55 \%$ & $57 \%$ \\
\hline
\end{tabular}


Notes: Figures are in percentage, except otherwise indicated. ${ }^{a}$ The additive individuals' perception of corruption in six specific measures of diversion of state budget, bribes for land titles, bribes for health care, bribes for primary education, bribes for construction permit, and bribes for state employment. ${ }^{b}$ The higher the value is the more people are unwilling to report corrupt behaviors.

Table 2 shows that corrupt practices were perceived more widely by citizens overtime. This is evidenced by annual increases in the overall level of corruption perception at in the period 20112014. On average, of six listed areas, respondents observed corruption at 1.7 in $2011,1.8$ in 2012, 1.9 in 2013, and 2.0 areas in 2014.

The other governance attributes indicate the stance of citizen participation, transparency, accountability. Among them, voting in local elections and willingness to report corruption exhibit the degree of citizen participation in governance at localities. Citizen participation seemed not improve overtime, as there were on average $71 \%-73 \%$ of people directly participated in election of the village heads in 2011-2013, and the figure dropped to $67 \%$ in 2014 . In addition, people seemed to more embrace of corrupt behaviors overtime, as the level of unwillingness to report corruption increased from 3.3 in 2011 to 4.3 in 2014.

In other aspects of good governance, transparency improved overtime, as there was an increase in the percentage of citizens reporting that commune budget and expenditure information was disclosed, from $64 \%$ in 2011 to $72 \%$ in 2014. Accountability was at low level but enhanced annually. Specifically, the percentage of citizen reporting the real effectiveness of the People's Inspection Board increased from 52\% in 2011 to $58 \%$ in 2014. Similarly, the percentage of citizen believed that provincial authorities are serious in dealing with corruption cases rose from $54 \%$ in 2011 to $57 \%$ in 2014.

Figure 1: Perception of six corruption practices 


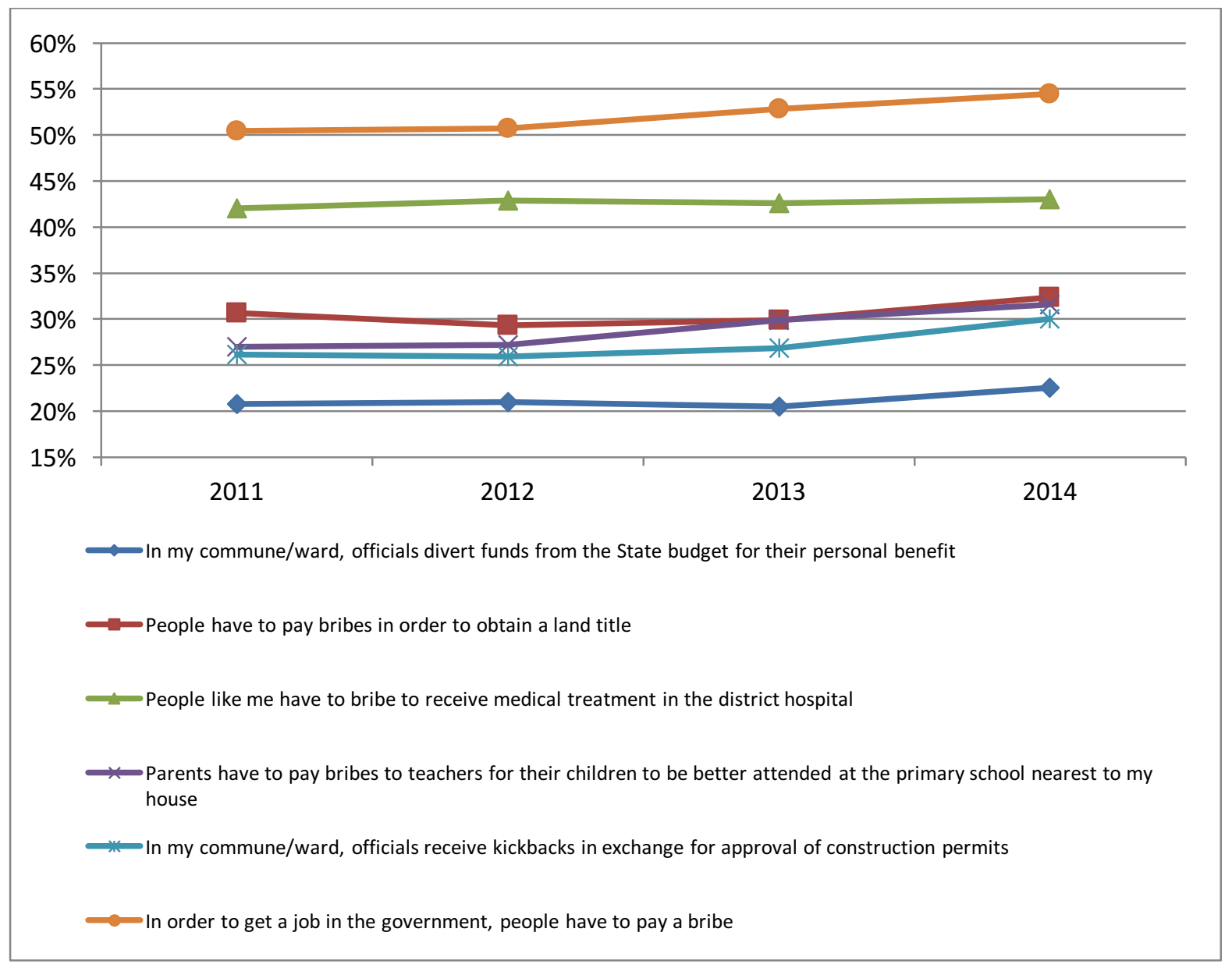

Figure 1 shows the levels of corruption perception over time in the six specific measures of corruption practices; namely diversion of state budget, bribes for land titles, bribes for health care, bribes for primary education, bribes for construction permit, and bribes for state employment. Among these practices, bribes for state employment is perceived the highest, as there were about 50 percent of the respondents in 2011 agreed that they had to pay bribe for employment in the public sector. This figure increased persistently and reached almost 55 percent in 2014 . The second highest corruption level is perceived in the health care sector. There were more than 40 percent of the citizens agreed that corrupt practices existed in this area, but remained stable over the period 2011-2014. Corruption in the primary education sector increased noticeably overtime, as seen through the percentage of respondents seeing the bribe for better attention from teachers increasing from $25 \%$ in 2011 to more than $30 \%$ in 2014. Corruption dynamics in handling of land titles and construction permits for citizens looked similar overtime. Corruption is perceived the least in the use of state funds, as less than $25 \%$ of the respondents over the period 2011-2014 agreed that public officials diverted state budget for their personal benefits.

Figure 2 shows a number of district-level aggregates that are believed to affect the interplay between corruption and the quality of public service delivery. In panel A the values of corruption 
perception corresponds to the right scale, while the values of the quality of public service delivery ${ }^{5}$ corresponds to the left scale. It is indicated that corruption in health care (at district hospitals) remained stable during the period from 2011-2014, having the mean value from 0.68 to 0.69 . $^{6}$ Corruption in primary education (at primary schools) were likely to increase over time, approaching the mean values of 0.46 and 0.48 respectively in 2013 and 2014, compared to those of 0.42 in the two previous years. Corruption is thus perceived more widely common in the health care sector than in the primary education sector. The quality of public health care and primary education seemed to improve during the period 2011-2014. As high as $83 \%$ of the respondents in 2011 valued the quality of health care at district hospitals, whilst this figure increased to $85 \%$ $86 \%$ in the following three years from 2012-2014. The quality of public primary education was even valued higher, as $87 \%$ of the respondents in 2011 assessed good quality of this kind of public service, while this figure uplifted to $89 \%-90 \%$ in the following three years.

Panel B presents some other district-level aggregates that might affect the quality of health care and primary education. The rate of poor household decreased annually from $16 \%$ in 2011 to $9 \%$ in 2014. In the meantime, the percentage of citizens having health insurance rose from $63 \% 2011$ to $68 \%$ in 2014 . The panel also shows additional indicators of infrastructure at localities such as national electricity, roads, and tab water supply. Almost all of the respondents indicated that they had national electricity, $98 \%-99 \%$. On the contrary, the percentages of citizens reported that they had access to paved or concrete roads and tab water supply were lower at $63 \%-68 \%$, and at $53 \%-59 \%$, respectively.

Panels $C$ and $D$ also indicate education levels and household economic conditions during the period from 2011-2014. The former shows that there were on average $64 \%-65 \%$ of the respondents having obtained high school education, $12 \%-13 \%$ having secondary education or less, and $22 \%-24 \%$ obtaining university education. The latter indicates that the percentage of citizens reporting the normal economic condition rose from $71 \%$ in 2011 to $74 \%$ in 2014 . In the meantime, the percentages of household having poor economic conditions decreased from $16 \%$ in 2011 to $13 \%$ in 2014 , and the rates of respondents reporting the good economic condition remained stable at $12 \%-13 \%$ during $2011-2014$.

Figure 2: Corruption, quality of public service delivery, and some other aggregates at the district level

\footnotetext{
${ }^{5}$ This is an averaged percentage, which represents a wide number of attributes denoting good quality of health care and primary education, respectively.

${ }^{6}$ This is an averaged-figure with scale ranging from $0-2$, which is different from the ratios as reported in Figure 1.
} 
Panel A: Corruption and quality of public service

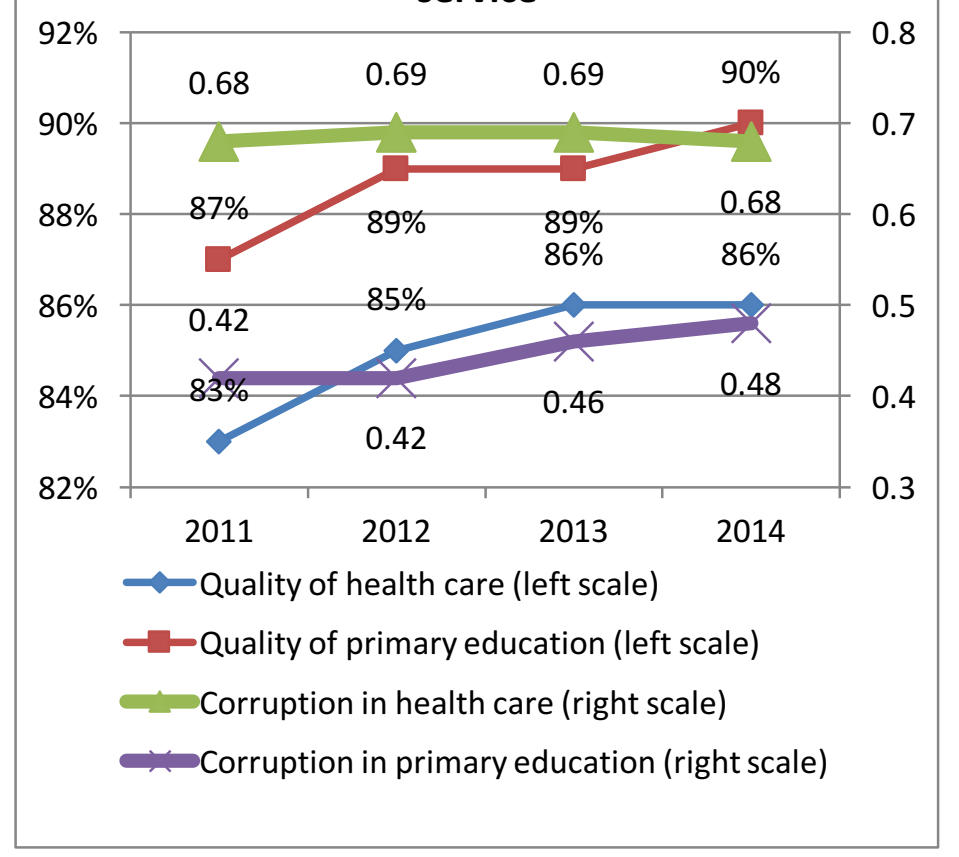

Panel C: Education levels

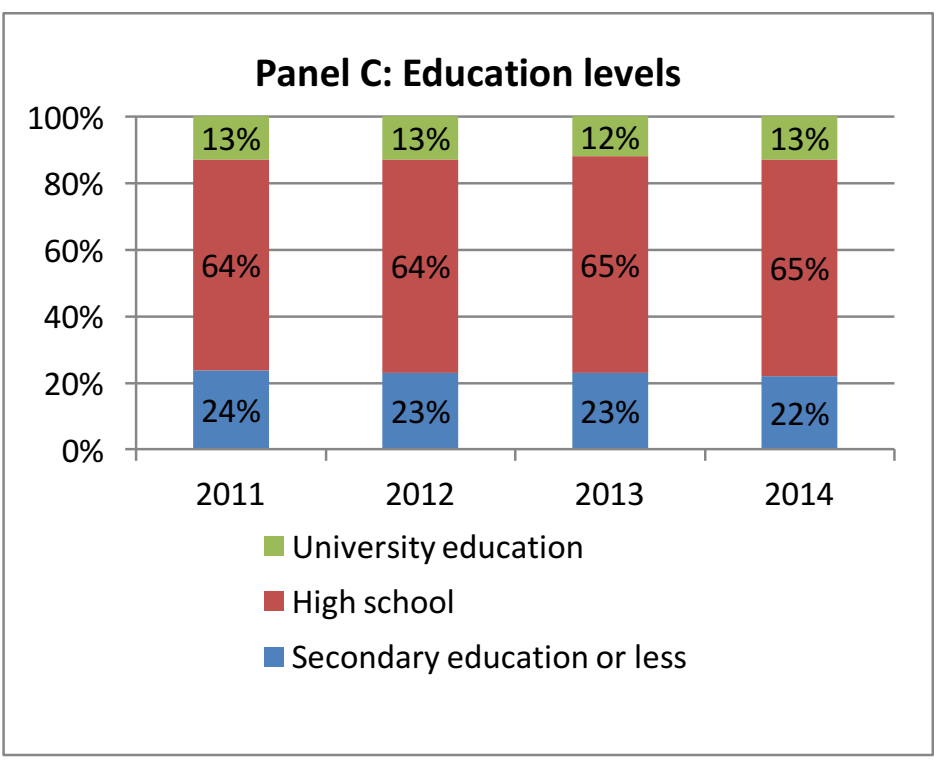

Panel B: Rate of poor household, health insurance, and infrastructure

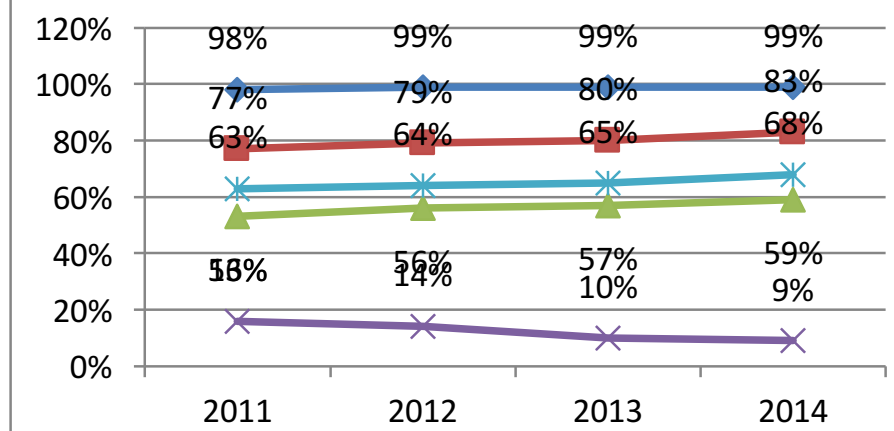

-Having national electricity

- Paved or concrete roads

- Tap water supply

$\leftarrow$ Rate of poor households

*Having health insurance

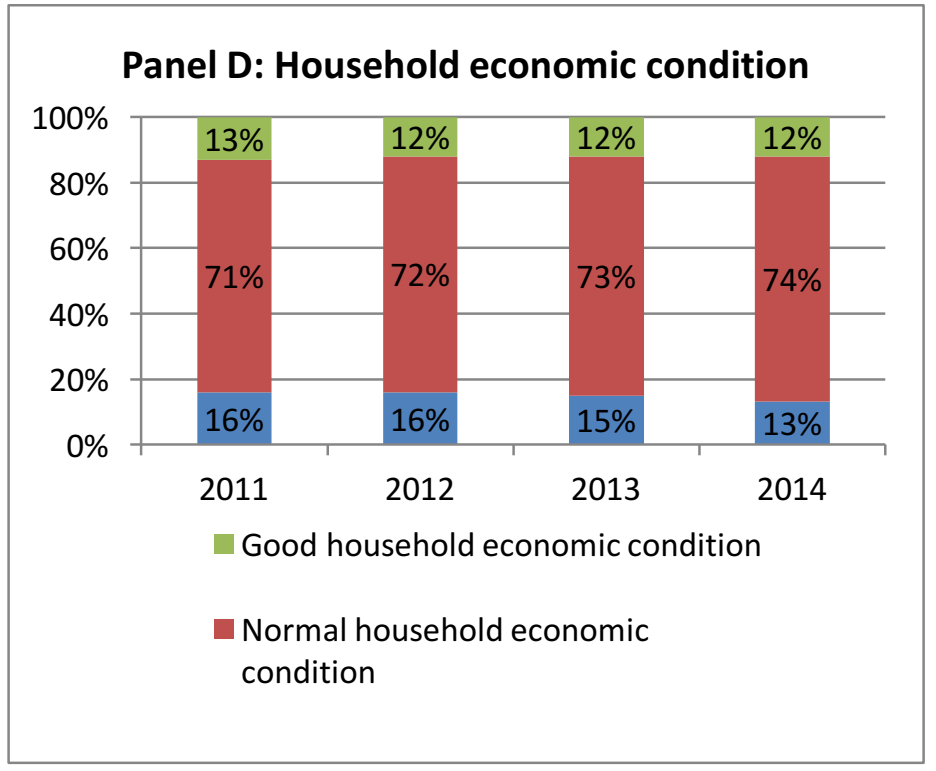

\section{Estimation strategy}

This section describes the benchmark econometric models for examining: (i) the effects of citizen participation, transparency, and accountability on corruption; and (ii) the effects of corruption on the quality of public service delivery, specifically in the health care and primary education sectors. The former is based on the individual-level data, and the latter is reliant on the district-level 
aggregated data. The data used in these two classes of models is in the four-year period from 2011 to 2014.

\section{The model for examining the effects of citizen participation, transparency, and accountability on corruption}

In this model, citizen participation, transparency, and accountability are more likely thought of the man-made design of governance in the public sector. In the meantime, corruption is one of the critical indicators that exhibit the quality of governance in the public sector. This first class of models is to examine whether changes in citizen participation, transparency, and accountability have significant effects on reducing corruption over time. Since the corruption measures used in this study are perception-based, they are prone to the selection bias. The respondents' readiness in reporting corruption behaviors, or practices, might be biased against their levels of knowledge, attentions, and whether in the past they worked in the public sector. There are two types of models to address this selection bias as specified below. First, in the outcome model, the Ordered Probit Model is employed to investigate whether citizen participation, transparency, and accountability might significantly reduce corruption. Second, in the selection model, the Ordered Probit Heckman's two-step procedure is employed to check whether the perception-based measure of corruption is subject to the selection bias.

\section{The outcome model}

In this model, the independent variable, the level of corruption, is regressed on the explanatory variables related to transparency, accountability and participation, while accounting for the other control variables:

$$
y_{i}=\alpha+\beta \boldsymbol{X}_{i}+\gamma \boldsymbol{Z}_{1 i}+\varepsilon_{1 i}(1)
$$

Where:

$\checkmark \quad y_{i}$ is ordered levels of corruption perceived by individual $i$;

$\checkmark \quad \boldsymbol{X}_{\boldsymbol{i}}$ is a vector of a number of governance covariates, including citizen participation, transparency, and accountability, which are experienced/perceived by individual $i$;

$\checkmark Z_{1 i}$ is a vector of the other control variables, including demographic factors and province-specific effects; and

$\checkmark \varepsilon_{1 i}$ is a usual random error term that is independently and identically distributed (i.i.d.).

The benchmark model (1) above is regressed on the individual-level data. The level of corruption is an additive measure of corruption perception perceived by individuals in the six areas of the state budget, land title, health care, primary education, construction permit, and public job recruitment. ${ }^{7}$ The ordered value of this measure ranges from zero to 6 , where zero means no corruption and 6 means the highest corruption. This outcome data pattern allows the employment of the Ordered Probit estimator for (1). There are two variables denoting citizen participation; namely voting in local election and unwillingness to report corruption. The former exhibits whether the individuals under survey directly participated in the direct voting of the village heads, and the latter measures the level of bribery amount to which the individuals under survey were ready to report to relevant authorities. The higher level of direct participation in elections is expected to curb corruption, as this helps improve the legitimacy of the people selected at the local authorities.

\footnotetext{
${ }^{7}$ Detail description of all the dependent and independent variables in the benchmark models (1) to (3) are
} presented in Appendix 3. Also, sources of data in the PAPI questionnaires are included. 
Also, citizen participation in reporting corruption helps enhance the detection mechanism. Three more variables represent the governance attributes that are expected to contain corruption, including transparency (measured by disclosure of commune budget and expenditure information), accountability (measured by effectiveness of People's Inspection Boards, and seriousness of local governments in dealing with corruption cases).

The benchmark model (1) also consists of the other demographic variables that are relevant to individual and household characteristics. These include gender, age, living experience, ethnic, education, profession, whether respondents are household heads, household sizes, and household economic conditions. Since the level of corruption is perception-based, controlling for these demographic characteristics is important. In addition, controlling for the province-specific effects deems salient, as the corruption perception may differ greatly across 63 provinces in Vietnam.

\section{The selection model}

In order to check whether the benchmark equation (1) is subject to the selection bias, a selection model is estimated first where the dependent variable $y_{i}$ in (1) is observed if

$$
\theta \boldsymbol{Z}_{2 i}+\varepsilon_{2 i}>0
$$

Where:

$\checkmark \quad Z_{2 i}$ is a vector of the covariates that are likely to determine whether $y_{i}$ is observed in (1). They include the individuals' level of education, their attention/interests in corruption, and whether they were in the past or currently public servants or members of mass organizations; and

$\checkmark \quad \varepsilon_{2 i}$ has the same property as $\varepsilon_{1 i}$ as above, and $\operatorname{Corr}\left(\varepsilon_{1 i}, \varepsilon_{2 i}\right)=\rho$ (Rho) is the correlation between the two random error terms in (1) and (2).

In essence, the two equations (1) and (2) are estimated simultaneously. The Wald test of independent equation will clarify whether the selection bias is a serious issue in the survey data. 


\section{The model for examining the effects of corruption on the quality of public service delivery}

To examine the effects of corruption on the quality of health care and primary education, the following benchmark model is employed:

$$
y_{i t}=\alpha+\beta \boldsymbol{X}_{i t}+\gamma \boldsymbol{Z}_{i t}+\vartheta_{i}+\varepsilon_{1 i}
$$

Where:

$\checkmark y_{i t}$ is the quality of health care/primary education as assessed by individuals aggregated up to district $i$ and in year $t(=2011,2012,2013,2014)$;

$\checkmark \quad \boldsymbol{X}_{i t}$ is the mean levels of corruption in the specific areas of health care and primary education in district $i$ and year $t$;

$\checkmark \quad Z_{i t}$ is a vector of the other covariates representing economic condition, coverage of health insurance (a determinant of health care), education, and general infrastructure in district $i$ and year $t$; and

$\checkmark \quad \vartheta_{i}$ is an unobservable district-specific effect, which differs across district but does not change over time; and

$\checkmark \quad \varepsilon_{1 i}$ is the usual random error term.

The factor of local economic conditions is a critical one to determine the quality of health care and primary education. There are two variables that deem to capture the economic condition at districts in the equation (3): rate of poor households and rate of households with normal and good economic conditions. The quality of health care is specifically affected by the ratio of people having health insurance in districts, denoted by the variable having health insurance. In addition, the quality of general infrastructure is likely to affect the access, and, in turn, the quality of these two public services. In this study the variables such access to national electricity, access to paved or concrete roads, and access to tap water supply represent the initial conditions of local infrastructure that might affect the quality of health care and primary education. In a certain district the ratios of individuals obtaining the levels of high school and university education are employed to control for citizen knowledge that might affect citizens' perception of the quality of public services. There are thus many factors working on the quality of health care and primary education at the district level. To address this issue, the equation (3) is estimated using the panel-data fixed effect regression. This estimator is advantageous over the other approaches, as it allows to rule out $\vartheta_{i}$ in (3), which account for a wide range of unobservable district-specific effects that presumably do not change overtime such as infrastructure, population density, remoteness, and the number of schools/hospitals in the districts. 


\section{Effects of citizen transparency, accountability, and participation on corruption}

Table 3 shows the regression results for the effects of citizen participation, transparency, and accountability on corruption. The model specification (1) in section 5 is estimated separately for every single year from 2011 to 2014. Table 3 also indicates that the disclosure of the commune budget and expenditure (transparency) helps reduce corruption in 2011, 2012, and 2014, but not in $2013 .^{8}$ This generally supports hypothesis $2 a$.

The empirical results also indicate that citizen participation in the voting of the villages' head negatively related to corruption across four years, but the more significant and profound effects are achieved in 2011 and 2012. In another aspect of citizen participation, unwillingness to report corruption is positively and significantly associated with corruption. Specifically, wherever people are less ready to report corrupt behaviors, corruption at their locality is more widespread. These results provide a solid support for $\mathrm{H} 2 \mathrm{c}$.

Another channel for curbing corruption is to enhance accountability in the public sector. The regression results in Table 3 show that the effectiveness of People's Inspection Boards contributes to contain corruption overtime, except for the year $2012^{9}$. The operation of these boards had larger and more statistically significant effects over time on reducing corruption in 2011-2014. Similarly, seriousness of local governments in dealing with corruption cases is significantly and negatively related to corruption. The will and determination of the provincial authorities seem to curb corruption, as there were large and consistent effects of this factor on reducing corruption overtime. The provincial authorities' willingness to seriously address corruption helps reduce corruption by the levels ranging from 0.436 in 2014 to 0.723 in 2012, higher than any other attributes of governance in Table 3 . Hypothesis $2 b$ is strongly supported.

Table 3: Effects of transparency, accountability and participation on corruption

\begin{tabular}{|c|c|c|c|c|}
\hline \multirow{2}{*}{$\begin{array}{l}\text { Dependent variable: } \\
\text { Overall corruption perception }\end{array}$} & \multicolumn{4}{|c|}{ Years } \\
\hline & 2011 & 2012 & 2013 & 2014 \\
\hline \multicolumn{5}{|l|}{ Governance attributes } \\
\hline \multirow[t]{2}{*}{$\begin{array}{l}\text { Disclosure of commune budget } \\
\text { and expenditure information }\end{array}$} & $-0.238^{* * *}$ & $-0.394^{* * *}$ & -0.064 & $-0.149^{* * *}$ \\
\hline & $(0.057)$ & $(0.068)$ & $(0.051)$ & $(0.040)$ \\
\hline Voting in local elections & $-0.137^{* *}$ & $-0.169^{* * *}$ & $-0.091^{*}$ & $-0.063^{*}$ \\
\hline \multicolumn{5}{|c|}{$\begin{array}{l}\text { This might be due to relatively high correlation between the two variables of commune budget and } \\
\text { xpenditure disclosure and the effectiveness of People's Inspection Boards (PIBs). The impact of commune } \\
\text { udget and expenditure disclosure could be confounded in the effectiveness of PIBs, leading to the } \\
\text { significant effect of the former in } 2013 \text {. }\end{array}$} \\
\hline \multicolumn{5}{|c|}{$\begin{array}{l}\text { This might be due to relatively high correlation between the two variables of commune budget and } \\
\text { xpenditure disclosure and the effectiveness of People's Inspection Boards. The impact of the effectiveness } \\
\text { f the People's Inspection Boards could be confounded in commune budget and expenditure disclosure, } \\
\text { ading to the insignificant effect of the former in } 2012 \text {. }\end{array}$} \\
\hline
\end{tabular}




\begin{tabular}{|c|c|c|c|c|}
\hline \multirow{2}{*}{$\begin{array}{l}\text { Dependent variable: } \\
\text { Overall corruption perception }\end{array}$} & \multicolumn{4}{|c|}{ Years } \\
\hline & 2011 & 2012 & 2013 & 2014 \\
\hline & $(0.059)$ & $(0.058)$ & $(0.051)$ & $(0.035)$ \\
\hline \multirow[t]{2}{*}{ Unwillingness to report corruption } & $0.046^{* * *}$ & $0.057^{* * *}$ & $0.044^{* * *}$ & $0.055^{* * *}$ \\
\hline & $(0.008)$ & $(0.009)$ & $(0.008)$ & $(0.006)$ \\
\hline \multirow[t]{2}{*}{$\begin{array}{l}\text { Effectiveness of } \\
\text { Inspection Boards }\end{array}$} & $-0.090^{*}$ & -0.027 & $-0.188^{* * *}$ & $-0.108^{* * *}$ \\
\hline & $(0.053)$ & $(0.046)$ & $(0.043)$ & $(0.035)$ \\
\hline \multirow[t]{2}{*}{$\begin{array}{l}\text { Seriousness of local governments } \\
\text { in dealing with corruption cases }\end{array}$} & $-0.643^{* * *}$ & $-0.723^{* * *}$ & $-0.680^{* * *}$ & $-0.436^{* * *}$ \\
\hline & $(0.054)$ & $(0.056)$ & $(0.040)$ & (0.038) \\
\hline \multicolumn{5}{|l|}{ Demographic variables } \\
\hline \multirow[t]{2}{*}{ Gender } & 0.055 & -0.013 & 0.059 & $0.112^{* * *}$ \\
\hline & $(0.055)$ & $(0.055)$ & $(0.046)$ & $(0.037)$ \\
\hline \multirow[t]{2}{*}{ Age } & -0.003 & -0.001 & -0.002 & $-0.006^{* * *}$ \\
\hline & $(0.003)$ & $(0.003)$ & $(0.002)$ & $(0.002)$ \\
\hline \multirow[t]{2}{*}{ Length of permanent residency } & 0.000 & 0.002 & -0.001 & -0.002 \\
\hline & $(0.002)$ & $(0.002)$ & $(0.002)$ & $(0.001)$ \\
\hline \multirow[t]{2}{*}{ Ethnicity } & 0.016 & 0.023 & 0.087 & -0.006 \\
\hline & $(0.076)$ & $(0.105)$ & $(0.082)$ & $(0.060)$ \\
\hline \multirow[t]{2}{*}{ University education } & $-0.266^{\star * *}$ & -0.115 & $-0.278^{\star *}$ & $0.219^{* * *}$ \\
\hline & $(0.098)$ & $(0.122)$ & $(0.112)$ & $(0.073)$ \\
\hline \multirow[t]{2}{*}{ High school } & 0.039 & $0.235^{*}$ & -0.082 & -0.030 \\
\hline & $(0.135)$ & $(0.139)$ & $(0.122)$ & $(0.058)$ \\
\hline \multirow[t]{2}{*}{ Family size } & -0.015 & $-0.033^{*}$ & -0.005 & 0.014 \\
\hline & $(0.016)$ & $(0.018)$ & $(0.013)$ & $(0.009)$ \\
\hline \multirow[t]{2}{*}{ Unskilled profession } & -0.092 & 0.039 & 0.065 & -0.045 \\
\hline & $(0.062)$ & $(0.078)$ & $(0.065)$ & $(0.047)$ \\
\hline \multirow[t]{2}{*}{ Skilled profession } & $-0.170^{* *}$ & -0.032 & 0.065 & 0.032 \\
\hline & $(0.081)$ & $(0.083)$ & $(0.078)$ & $(0.057)$ \\
\hline \multirow[t]{2}{*}{ Business owner } & -0.050 & 0.043 & $0.169^{*}$ & 0.050 \\
\hline & $(0.104)$ & $(0.103)$ & $(0.087)$ & $(0.063)$ \\
\hline \multirow[t]{2}{*}{ Household head } & -0.024 & 0.010 & 0.026 & -0.007 \\
\hline & $(0.062)$ & $(0.059)$ & $(0.045)$ & $(0.039)$ \\
\hline \multirow[t]{2}{*}{ Normal economic condition } & $-0.152^{*}$ & -0.062 & -0.072 & $-0.203^{* * *}$ \\
\hline & 22 & & & \\
\hline
\end{tabular}




\begin{tabular}{lcccc}
\hline \multirow{2}{*}{$\begin{array}{l}\text { Dependent variable: } \\
\text { Overall corruption perception }\end{array}$} & 2011 & 2012 & 2013 & 2014 \\
\cline { 2 - 5 } & $(0.087)$ & $(0.087)$ & $(0.069)$ & $(0.060)$ \\
Good economic condition & $-0.204^{* *}$ & -0.160 & -0.070 & $-0.202^{* * *}$ \\
& $(0.093)$ & $(0.109)$ & $(0.085)$ & $(0.068)$ \\
Provincial-specific effect & Yes & Yes & Yes & Yes \\
\hline Pseudo R-squared & $7.2 \%$ & $8.0 \%$ & $6.5 \%$ & $4.4 \%$ \\
Number of observations & 2,194 & 2,264 & 3,149 & 4,961 \\
\hline
\end{tabular}

Notes: Standard errors are in parentheses and robust to the cross sectional dependence within districts. ${ }^{* * *} p<0.01,{ }^{* *} p<0.05,{ }^{*} p<0.1$.

With respect to the other control variables, the empirical results show that there are no significantly consistent impacts of gender, age, length of permanent residency, ethnic, family size, profession, the status of household's head on the corruption levels as perceived by individuals in 2011-2014. Some other demographic variables such as education and household's economic condition have significant effects in selective years. For example, citizens with university education are likely to judge corruption significantly lower than those with secondary education or less in 2011 and 2013, but not in 2014. There is thus no clear cut between the levels of corruption as perceived by people with high and low educations over time. The individuals living in household with good and normal economic conditions judge corruption less severely than those living in household with poor economic conditions. In 2014 the former perceive corruption lower by the level of about 0.2 than the latter.

\section{Controlling for selection bias}

Since corruption is a sensitive issue, the perception-based measure of corruption is likely biased against a number of individuals' characteristics such as education, attention to news, and whether they are currently or previously members of mass organizations or public servants. If this is a serious issue, the corruption levels as reported by individuals are subject to the selection bias where in the first step people are not aware of the corruption practices, or do not feel comfortable in reporting corruption. We addressed this issues by using the Ordered Probit Heckman's two step procedures where the benchmark models (1) and (2) in the empirical strategy section are estimated simultaneously. Although the variables like education, attention to news, and whether they are currently or previously members of mass organizations or public servants seem to constrain citizen perception of corruption, the Wald test of independent equations rejects the independent equations, indicating that the selection bias in the PAPI data is not a serious issue. The empirical results in Table 2 could thus be used for empirical analysis and policy discussions.

\section{Effects of corruption on the quality of public health care and primary education}

Since corrupt behaviors extract valuable resources in the delivery of public services, they are expected to lower the quality of public services as received by the beneficiaries, or the end-users. Table 4 and Table 5 respectively show the estimated results for the effects of corruption on the quality of health care and primary education, after having controlled the other factors deemed to affect the services' quality at localities.

\section{Effects of corruption on the quality of public health care}


There are three model specifications in Table 4, where the relevant control variables are subsequently included in the regressions. The overall empirical findings across specifications (1) to (3) indicate that corruption has the negative effects on the quality of health care. These effects are statistically significant at the very high level of one percent, and consistent in magnitude across all the specification equations. Hypothesis 1a was supported.

Table 4: Corruption and the quality of health care

Dependent variable:

Averaged quality of health care

(1)

(2)

(3)

Perception of corruption in public health

care

$-0.070^{* * *}$

$-0.057^{* * *}$

$-0.063^{* * *}$

Rate of poor households

(0.013)

(0.013)

(0.014)

Rate of poor households

$-0.107^{* * *}$

$-0.126^{\star * *}$

Having health insurance

(0.030)

(0.040)

$0.062^{* *}$

$0.063^{* *}$

(0.027)

(0.029)

High school

$-0.003$

(0.040)

University education

$-0.160^{* * *}$

(0.053)

$-0.057$

Normal household economic condition

(0.044)

Good household economic condition

$-0.137^{* *}$

(0.054)

0.048

Access to national electricity

Access to paved or concrete roads

Access to tap water supply

\begin{tabular}{lccc}
\hline Number of observations & 824 & 788 & 719 \\
R-squared (within) & $4.7 \%$ & $6.6 \%$ & $12.3 \%$ \\
\hline
\end{tabular}

Notes: Standard errors are in parentheses. ${ }^{* *} p<0.01,{ }^{* *} p<0.05,{ }^{*} p<0.1$. 
With respect to the other determinants of health care, in the specification equations (2) and (3), the districts with the higher rates of poor households have significantly lower quality of health care. This finding raises concerns over the most disadvantageous districts in Vietnam, where prolonged poverty could deteriorate basic health care for the local people. The status of having health insurance could also have potential effects on the quality of health care at district hospitals. The specifications (2) and (3) manifest that having health insurance raise the quality of health care as perceived by individuals, which is independent of education and economic conditions as indicated in (3). Specifically, the districts with the higher rates of people having health insurance is associated with the higher quality of health care. This could lay a foundation for the plan of making health insurance universal as currently undertaking by the government. In the districts with the higher rates of people having university education, the quality of health care is on average perceived lower. This finds evidence in the specifications (3), as the estimated coefficients for the variable university education are both negative and statistically significant at the level of one percent and five percent, respectively. Additionally, in those districts with the higher rates of households with good economic condition, the quality of health care is also perceived lower as indicated in the specifications (3). These findings might be grounded on the fact that people with higher education and better household economic conditions are better aware of, and have a higher demand as well for, the quality of public services, resulting in the lower quality of health care as exhibited in the regression equations.

\section{Effects of corruption on the quality of public primary education}

Table 5 shows that corruption has a negative relationship with the quality of primary education at the district level. These effects are statistically significant and consistent in magnitude across the three model specifications from (1) to (3). Specifically, the estimated coefficients for the variable corruption perception in primary education basically remain unchanged when further control variables are included in the relevant regression models. Hypothesis $1 \mathrm{~b}$ is supported.

In comparison with the health care sector, corruption seems to affect the primary education less severely due to its universal coverage and free access (in the public schools). The variable rate of poor household is included in the specification (2), and the estimated coefficient shows that the quality of primary education is negatively associated with the rate of poor households, but this effect is no longer statistically significant in (3) where additional control variables are included. The household economic condition related positively to the quality of primary education; namely, the quality is perceived higher in the districts with the higher rates of households having the good economic condition compared to those having the poor economic conditions. In addition, the conditions of the local infrastructure related to paved/concrete roads and the national electricity's access have a positive association with the quality of primary education. These results are noticeable, as the infrastructure of this kind has no significant effects on the quality of health care as indicated in Table 4. The different effects could be explained on the ground that the primary education is more regularly reliant on the access to the national electricity and to paved/concrete roads than health care services. 
Dependent variable:

Quality of primary education

(1)

(2)

\begin{tabular}{lccc}
\hline $\begin{array}{l}\text { Perception of corruption in public primary } \\
\text { education }\end{array}$ & $-0.040^{* * *}$ & $-0.033^{* *}$ & $-0.037^{* *}$ \\
Rate of poor households & $(0.014)$ & $(0.015)$ & $(0.015)$ \\
High school & $-0.124^{* * *}$ & 0.035 \\
& & $(0.031)$ & $(0.039)$ \\
University education & & -0.005 \\
& & & $(0.040)$ \\
Normal household economic condition & & 0.054 \\
Good household economic condition & & $(0.052)$ \\
Access to national electricity & & 0.044 \\
Access to paved or concrete roads & & $(0.044)$ \\
Access to tap water supply & & $0.120^{* *}$ \\
\hline Number of observations & & $(0.053)$ \\
\hline
\end{tabular}

Note: Standard errors are in parentheses. ${ }^{* *} p<0.01,{ }^{* *} p<0.05,{ }^{*} p<0.1$.

\section{Discussions}

We set out in this study to empirically examine whether or not citizen participation, transparency, and accountability are associated with less corruption, and whether lower levels of corruption relate to better public service quality. The PAPI data is ideal for us to conduct these examinations in the Vietnamese context.

Our results show that persistent corruption is associated with low quality education and healthcare services. This is contrary to the "greasing the wheels" notion which suggests that corruption adds good value to developing countries (Meon \& Sekkat, 2005). While bribes may speed up some administrative procedures and provide incentives for better services, these effects are largely short-term, transaction-specific, and only applied to those who can afford to bribe. The long-term 
losses of innovation, commitment, and morality of service delivery staff are much more damaging, as seen in other studies (see Gabel, 2012; Nguyen et al., 2016 for example). Where corruption is prevalent, public service delivery personnel pay attention to getting bribes or informal payments from citizens and are distracted from improving quality of service. Worse still, some of the resources designated to the primary education and health care at the district level may be drained by corrupt behaviors by the time they reach the end-users. This damage is especially serious in poor countries where commitment, morality, and innovation are very fragile in the public sector. Future research should detangle possible short-term, transaction-specific positive effects from long-term, overall damages of corruption on public service deliveries.

The research also provides evidence that in developing countries like Viet Nam, TA\&P help reduce corruption. The results support the "good governance" hypothesis which proposes that TA\&P are effective anti-corruption strategies, even in developing countries (see Kaufmann, 2005; Wells-Dang, Le, \& Nguyen, 2015). It is important to note that the data in this research captures corruption practices in public primary education and public healthcare at the local level. Whether TA\&P would have a similar impact on corruption in other sectors, (as queried in Khan, 2006; Spector, 2005) remains a topic for further research.

Our research relates to public servants' accountability to citizens, an often-neglected type of accountability in developing countries (Brinkerhoff, 2004; Devas \& Grant, 2003). The results show that accountability to citizens most strongly reduces corruption. While we conceptualize participation, accountability, and transparency as three attributes of local governance, it is likely that transparency and participation are preconditions of accountability, as supported by Devas \& Grant (2003), and Wells-Dang, Le, and Nguyen (2015). This complex relationship among TA\&P deserves further examination.

In Vietnam's transition, good governance principles in a market economy are struggling with the inertia of the state control, rooted in the traditional socialist system (Martin, 2008). We have shown that TA\&P contribute to anti-corruption results, which further help improve public service quality. Yet, the promotion of these good governance principles remains a challenge in Viet Nam. The challenge comes not only from the limited capability of government officials but also from the equivocality of the development ideology as Nguyen (2005) discussed. It would be interesting to examine which mechanisms are effective in promoting TA\&P under such dual development ideology. 


\section{Policy Implications}

Our study offers several recommendations for consideration in government policy making to enhance local governance and to reduce corruption. These suggestions speak to the key attributing factors under discussion of this research paper: citizen participation, transparency and vertical accountability.

First, active citizen participation in local political life through transparent and fair elections of village heads is critical. So is it for citizen engagement in reporting corruption however petty the corruption practices is. Promoting citizen activism in the political context of Viet Nam requires the openness and pro-activeness of both sides of the coin: the citizenry and the government. With a more rights-based constitutional foundation set forth in the 2013 Constitution, together with the support of new technology and more open media, there is light of hopes for greater genuine citizen participation for better governance in Viet Nam in the years to come.

Second, genuine participation is hard to obtain in anti-corruption agendas when citizens are not encouraged to report against any wrong doings by public officials and when they feel they are not protected when taking anti-corruption initiatives. As our research has shown, citizens' willingness to report corrupt practices decreased in the period from 2011-2014. Promoting the roles of media and civil society to be the intermediary platforms for citizens to report on corruption will help central and local governments to prevent corruption. Upcoming revisions to anti-corruption legislations should spell this out more profoundly so as to improve the effectiveness of anti-corruption work in Viet Nam.

Third, citizen participation and the accountability mechanism like People's Inspection Boards would be meaningless if transparency is not respected. In the last decade, the need for more transparency and information disclosure has been well recognized. However, the relevance (i.e. the level of details and disaggregation of data) and quality (i.e. the reliability and timeliness) of information needs to be improved. In an essence, disclosure of budget and expenditure information helps reduce corruption at local levels while more access to other types of government information would be necessary to enhance anti-corruption effectiveness. It is timely for a Law on Access to Information that facilitates rather than policing access to information to be promulgated. The law will serve as a legal framework to foster transparency and engage citizens and institutions in calling central and local governments into account and keeping public service delivery agencies under check to better control corruption. In addition, building strong databases in important areas, such as a land registrar system and an open budget system for both central and local governments, would be critical in promoting citizen access to information.

Third, accountability to citizens and non-state actors need to be fostered among public officials and civil servants. As the research and UNDP, CECDES and VFF (2014) have pointed out, it is important to improve the effectiveness of the People's Inspection Boards, the grassroots monitoring mechanisms by citizens to keep the performance of public officials and civil servants under check. By giving PIBs enlarging space, necessary skills and easy-to-follow toolkits, these boards will exercise their mandates and power as promulgated in the Ordinance on Grassroots Democracy and the Law on Inspection. In order for PIBs to be effective, citizen participation in selection of their members is a must.

Last but not the least, fostering good governance means that the government needs to gain a considerable trust from the public. To this end, there should be a fundamental shift in the mindset and attitude of public officials. Providing good information to the public, inviting the public to participate in policy agenda, and responding accountably to the public concerns are good mechanisms to gain trust and fight corruption. 
Ades, A., \& Di Tella, R. (1999). Rents, competition and corruption. The American Economic Review, Vol. 89, 982-993.

Aidt, T.S. (2003). Economic analysis of corruption: a survey. The Economic Journal, Vol. 113, 632-652.

Aidt, T.S., Dutta, J., \& Sena, V. (2008). Governance regimes, corruption and growth: theory and evidence. Journal of Comparative Economics, Vol. 36, 195-220.

Anderson, S., \& Heywood, P.M. (2009). The politics of perception: use and abuse of Transparency International's approach to measuring corruption. Political Studies, Vol. 57, 746-767.

APIM. (2010). Asia Pacific Institute of Management. "Education Decentralization in Viet Nam" Research Report for Oxfam Great Britain.

Arab/Afrobarometer. (2013). The quality of democracy and governance in Algeria.

Azfar, O., \& Gurgur, T. (2008). Does corruption affects health outcomes in the Philippines? Economics of Governance, Vol. 9, 197-244.

Baiocchi, G. (2003). Emerging public spheres: Talking politics in participatory governance, American Sociological Review, 68(1): 52 - 74.

Bardhan, P. (1997). Corruption and development: a review of issues. Journal of Economic Literature, Vol. 35(3), 1320-1346.

Bardhan, P., \& Mookherjee, D. (2006). Decentralization, corruption and government accountability. In: Rose-Ackeman, S. (Eds.). International handbook on the economics of corruption. Cheltenham: Edward Elgar, 161-188.

Becker, G.S. (1968). Crime and punishment: an economic approach. Journal of Political Economy, Vol. 76, 169-217.

Brinkerhoff, D.W. (2004). Accountability and health systems: toward conceptual clarity and policy relevance. Health Policy and Planning, Vol. 19, 371-379.

Brunetti, A., \& Weder, B. (2003). A free press if bad news for corruption. Journal of Public Economics, Vol. 87, 1801-1824.

Cai, H., Fang, H., \& Xu, C.L. (2009). Eat, drink, firms and government: an investigation of corruption from entertainment and travel costs of Chinese firms. Journal of Law and Economics, Vol. 54(1), 55-78.

Campante, F., \& Do, Q.A. (2014). Isolated capital cities, accountability and corruption: evidence from US states. American Economic Review, Vol. 104(8), 2456-2481.

CECODES, VFF-CRT \& UNDP (2015). Viet Nam Provincial Governance and Public Administration Performance Index 2014: Measuring citizen's experiences, Policy Report among CECODES, VFF-CRT and UNDP, Hanoi, Vietnam.

CPV (2004). Documents of the Party Central Committee $9^{\text {th }}$, National Political Publishing House.

Deininger, K., \& Mpuga, P. (2005). Does greater accountability improve the quality of public service delivery? Evidence from Uganda. World Development, Vol. 33(1), 171-191. 
Devas, N, \& Grant, U. 2003. Local government decision-making-citizen participation and local accountability: Some evidence from Kenya and Uganda. Public Administration and Development. 23: 307-316.

Dollar, D., Fisman, R., \& Gatti, R. (2001). Are women really the "fairer" sex? Corruption and women in government. Journal of Economic Behaviours and Organization, Vol. 46, 423429.

Dong, B. (2011). The causes and consequences of corruption. PhD thesis submitted at Queensland University of Technology.

Dreher, A., \& Gassebner, M., 2013. Greasing the wheels? The impact of regulations and corruption on firm entry. Public Choice, 155:413-432.

Embassy of Finland and SECODES (2008). Anti-corruption in Vietnam: Situation after two years of implementation of the law, Policy Report, Hanoi

Fisman, R., \& Gatti, R. (2002a). Decentralization and corruption: evidence across countries. Journal of Public Economics, Vol. 83, 325-345.

Fisman, R., \& Gatti, R. (2002b). Decentralization and corruption: evidence from US Federal transfer programs. Public Choice, Vol. 113, 25-35.

Fitzsimons. G. V. (2009). A troubled relationship: corruption and reform of the public sector in development. Journal of Management Development, 28(6): 513 - 521.

Fredriksson, P.G., List, J., \& Millimet, D.L. (2003). Bureaucratic corruption, environmental policy and inbound US FDI: theory and evidence. Journal of Public Economics, Vol. 87, 14071430.

Freille, S., Haque, M. E., \& Kneller, R. (2007). A contribution to the empirics of press freedom and corruption. European Journal of Political Economy, Vol. 23, 838-862.

Garcia-Zamor, J., 2015. Quality of Governance and Ethical Public Service Delivery (PSD) in Developing Countries. Journal of Management and Strategy, 6.3 (2015): 28 - 37.

Gebel, C. A. (2012). Human nature and morality in the anti-corruption discourse of Transparency International. Public Administration \& Development, 32.1: 109 - 128.

Gerring, J., \& Thacker, S.C. (2005). Do neoliberal policies deter political corruption? International Organization, Vol. 59, 233-254.

GI \& UNCAC (2010). A study of corruption risks behaviors in education, Hanoi, 19 May 2010 (donors' roundtable to prepare the 7th ACD)

Giedon, U., Morales, L.G., \& Acosta, O.L. (2001). The impact of health reforms on irregularities in Bogota hospitals. In: Di Tella, R. and Savedoff, W. (eds). Diagnosis corruption: fraud in Latin America's public hospitals. Inter-American Development Bank Press.

Goel, R.K., \& Nelson, M.A. (2007). Are corrupt acts contagious? Evidence from the United States. Journal of Policy Modelling, Vol. 29, 839-850.

Goetz, A.M. (2007). Political cleaners: women as the new anti-corruption force? Development and Change, Vol. 38(1), 87-105.

Hors, I. (2000). Fighting corruption in the developing countries. Organization for Economic Cooperation and Development. The OECD Observer 220 : 43-45.

Indochina Research consulting (2012). Household informal disbursement for education in Vietnam, Hanoi, Vietnam. 
Jain, A.K. (2001). Corruption: a review. Journal of Economic Surveys, Vol. 15, 71-121.

Johnston, M. (1986). Right and wrong in American politics: popular conceptions of corruption. Polity, Vol. 18, 367-391.

Kaufmann, D. (1997). Corruption: the facts. Foreign Policy, Vol. 107, 114-131.

Khan, M. H., (2006). Determinants of Corruption in Developing Countries: the Limits of Conventional Economic Analysis, in Rose-Ackerman, Susan (ed.) International Handbook on the Economics of Corruption, pp. 216-44, Cheltenham: Edward Elgar.

Khan, M. H., Nguyen, V. T., \& Nguyen, V. H. (2015). Administrative Appointments in Vietnamese Universities: A Sectorial Analysis of Feasible Anti-Corruption Strategies. Research Report to DFID, Hanoi.

La Porta, R., Lopez-de-Silanes, F., Shleifer, A., \& Vishny, R.W. (1999). The quality of government. Journal of Law, Economics and Organization, Vol. 15, 222-279.

Lambsdorff, J.G. (2004). Background paper to the 2004 Corruption Perceptions Index. Retrieved from: http://www.icgg.org/downloads/CPI_methodology.pdf

Lamour, P. (2012). Interpreting corruption: culture and politics in the Pacific Islands. Honolulu: University of Hawaii Press.

Lavena, C.F. (2013). What determines permissiveness toward corruption? A study of attitudes in Latin America. Public Integrity, Vol. 15(4), 345-365.

Leff, N. H. (1964). Economic development through bureaucratic corruption. American Behavioral Scientist, 8(3), 8-14.

Leite, C. and Weidmann, J. (1999). Does mother nature corrupt? Natural resources, corruption and economic growth. IMF Working Paper No. 99/85.

Leys, C. (1965). What is the problem about corruption? Journal of Modern African Studies, 3(2), 215-230.

Lui, F.T. (1985). An equilibrium queuing model of bribery. Journal of Political Economy, Vol. 93, 760-781.

Lou, Y. (2002). Corruption and organization in Asian management system. Asia Pacific Journal of Management, 19, 405 - 422.

Martini, M. (2012). Overview of corruption and anti-corruption in Vietnam, U4 Expert Answer, Transparency International, No. 315

Mauro, P. (1998). Corruption and the composition of government expenditure. Journal of Public Economics, Vol. 69, 263-279.

Melgar, N., Rossi, M., \& Smith, T. (2010). The perception of corruption. International Journal of Public Opinion Research, Vol. 22(1), 120-131.

Meon, P.-G., \& Sekkat, K. (2005). Does corruption grease or sand the wheels of growth? Public Choice, 122(1), 69-97.

Meon, P.-G., \& Weill, L. (2010). Is corruption an efficient grease? World Development, 38(3), 244259.

Mohtadi, H., \& Roe, T.L. (2003). Democracy, rent seeking, public spending and growth. Journal of Public Economics, Vol. 87, 445-466. 
Murphy, K.M., Shleifer, A., \& Vishny, R.W. (1991). The allocation of talent: implications for growth. Quarterly Journal of Economics, Vol. 106, 503-530.

Murphy, K.M., Shleifer, A., \& Vishny, R.W. (1993). Why is rent-seeking so costly for growth? American Economic Review, Vol. 83, 409-414.

Nguyen, D. C. (2007). Corruption in general education in Vietnam, Study Report, Institute of Population and Social Studies, National Economics University.

Nguyen, V. T., Ho, D. B., Le, Q. C., \& Nguyen, V. H. (2016). Strategic and transactional costs of corruption: Perspectives from Vietnamese firms. Journal of Law, Justice, and Social Change (forthcoming).

Nguyen, V. T., Le, Q. C., Tran, T. B., \& Bryant, S. (2015). Citizen Participation in City Governance: Experiences from Vietnam. Public Administration and Development, 35: 34 - 45.

Khan, M., Nguyen, V.T., \& Nguyen, V.H. (2015). Recruitment and promotions in higher education, Presentation at UNDP Workshop in Hanoi.

NORAD (2011). Joint evaluation of support to anti-corruption efforts Vietnam Country Report, Report 6/2011, Evaluation Department.

Otusanya, J. O. (2011). Corruption as an obstacle to development in developing countries: a review of literature. Journal of Money Laundering Control. Vol. 14 No. 4: 387 - 421.

Pandey, P. (2010). Service Delivery and Corruption in Public Services: How Does History Matter? American Economic Journal: Applied Economics, 2 (3): 190 - 204.

Painter, M. (2008). From Command Economy to Hollow State? Decentralisation in Vietnam and China. Australian Journal of Public Administration, 67.1: 79-88.

Pellegrini, L., \& Gerlagh, R. (2004). Corruption's effect on growth and its transmission channels. Kyklos, Vol. 57, 429-456.

Pellegrini, L., \& Gerlagh, R. (2006). Corruption, democracy and environmental policy: an empirical contribution to the debate. Journal of Environment and Development, Vol. 15, 332-354.

Pillay, S. (2004). Corruption - the challenge to good governance: a South African perspective. The International Journal of Public Sector Management, 17 (6/7), 586-605.

Rose-Ackerman, S. (1999). Corruption and government: causes, consequences, and reform. Cambridge: Cambridge University Press.

Samaratunge, R., and Wijewardena, N., (2009). The Changing Nature of Public Values in Developing Countries. International Journal of Public Administration, 32.3/4 : 313.

Salifu, A. (2008). Can corruption and economic crime be controlled in developing economies and if so, is the cost worth it? Journal of Money Laundering Control, 11(3): $273-283$.

Schuler, P., \& Badiani, R. (2013). Corruption in public service delivery: informal fees in education and healthcare in Vietnam. Mimeograph.

Seligson, M.A. (2002). The impact of corruption on regime legitimacy: a comparative study of four Latin American countries. The Journal of Politics, Vol. 64(2), 408-433.

Soares, R.R. (2004). Crime reporting as a measure of institutional development. Economic Development and Cultural Change, Vol. 52(4), 851-871.

Spector, Bertram I. (ed.) 2005. Fighting Corruption in Developing Countries: Strategies and Analysis. Bloomfield CT: Kumarian Press. 
Tanzi, V. (1998). Corruption around the world: causes, consequences, scope and cures. IMF Staff Papers, Vol. 45, 559-594.

Tanzi, V., \& Davoodi, H. (1997). Corruption, public spending and growth. IMF Working Paper, WP/97/139.

Transparency International (2013). Global corruption barometer. Berlin: Transparency International.

Transparency International (2015). https://www.transparency.org/topic/detail/education/.

Treisman, D. (2000). The causes of corruption: a cross-national study. Journal of Public Economics, Vol. 76, 399-457.

Treisman, D. (2007). What have we learned about the causes of corruption from ten years of cross-national empirical research? Annual Review of Political Science, Vol. 10, 211-244.

Truex, R. (2011). Corruption, attitudes and education: survey evidence from Nepal. World Development, Vol. 39(7), 1133-1142.

UNDP, VFF, \& CECODES. (2013). The Vietnam provincial governance and public administration reform index: 2012.

UNDP, VFF, \& CECODES. (2014). The Vietnam provincial governance and public administration reform index: 2013.

vanRijkeghem, C., \& Weder, B. (2001). Bureaucratic corruption and the rate of temptation: do wages in the civil service affect corruption and by how much? Journal of Development Economics, Vol. 65, 307-331.

VCCI \& USAID (2013). Provincial Competitiveness Index 2012 of Vietnam, Policy Report between Vietnam Chamber of Commerce and Industry (VCCI) and U.S Agency for International Development (USAID)

VCCI \& USAID (2015). Provincial Competitiveness Index 2014 of Vietnam, Policy Report between Vietnam Chamber of Commerce and Industry ( $\mathrm{VCCl})$ and U.S Agency for International Development (USAID).

Vial, V., \& Hanoteau, J. (2010). Corruption, manufacturing plant growth, and the Asian paradox: Indonesian evidence. World Development, 38(5), 693-705.

Vian, T. (2007). Review of corruption in health sector: theory, methods and interventions. Health Policy and Planning, Vol. 23(2), 83-94.

Walton, G. (2015). Defining corruption where the State is weak: the case of Papua New Guinea. Journal of Development Studies, Vol. 51(1), 15-31.

Walton, G., \& Peiffer, C. (2015). The limitations of education for addressing corruption: lessons from attitudes towards reporting in Papua New Guinea. Crawford School of Public Policy's Development Policy Discussion Paper, No. 39. Canberra: The Australian National University.

WB \& GI (2012). Corruption from the perspective of citizens, firms, and public officials: Results of Sociological Survey, National Political Publishing House, Hanoi

WB (2007). Strengthening World Bank Group engagement on governance and anti-corruption. Washington DC: World Bank.

WB (2009). Vietnam development report 2010: modern institutions. Washington, D.C

WB (2010). Vietnam Development Report Modern Institutions, World Bank: Hanoi, Vietnam 
WB (2012). Health equity and financial protection report-Vietnam, Washington D.C.: World Bank

WB (2014a). The Worldwide Governance Indicators, Natural Resource Governance Institute, the Brookings Institutions, The World Bank.

WB, 2015. Vietnam Anti-corruption Initiatives Final Evaluation. Hanoi: The World Bank.

Wei, S. (2000). How taxing is corruption on international investors? The Review of Economics and Statistics, Vol. 82, 1-11.

Wells-Dang, A., Le, K. T., and Nguyen, T. L. (2015). Between Trust and Structure: Citizen Participation and Local Elections in Viet Nam. A Joint Policy Research Paper on Governance and Participation commissioned by Oxfam in Viet Nam and the United Nations Development Programme (UNDP) in Viet Nam. Ha Noi, Viet Nam: August 2015.

Welsch, H. (2004). Corruption, growth and the environment: a cross-country analysis. Environmental and Development Economics, Vol. 9, 663-693.

Welter, F., and Smallbone, D., 2011. Institutional Perspectives on Entrepreneurial Behavior in Challenging Environments. Journal of Small Business Management, 49(1): 107-125.

World Bank (2007). Strengthening World Bank Group engagement on governance and anticorruption. Washington DC: World Bank.

Zhou, J. Q and Peng, M. W. Does bribery help or hurt firm growth around the world?_Asia Pacific Journal of Management, 29(4): 907-921. 
Table 1: Effects of citizen participation, transparency, and accountability on corruption (controlling for selection bias)

\begin{tabular}{|c|c|c|c|c|}
\hline \multirow{2}{*}{$\begin{array}{l}\text { Dependent variable: } \\
\text { Overall corruption perception }\end{array}$} & \multicolumn{4}{|c|}{ Years } \\
\hline & 2011 & 2012 & 2013 & 2014 \\
\hline \multicolumn{5}{|l|}{ Governance's attributes } \\
\hline \multirow[t]{2}{*}{ Voting in local election } & $-0.132^{* *}$ & $-0.174^{* * *}$ & $-0.091^{*}$ & $-0.065^{*}$ \\
\hline & $(0.060)$ & $(0.057)$ & $(0.051)$ & $(0.035)$ \\
\hline \multirow[t]{2}{*}{$\begin{array}{l}\text { Disclosure of commune budget and } \\
\text { expenditure information }\end{array}$} & $-0.228^{* * *}$ & $-0.395^{\star * *}$ & -0.067 & $-0.150^{* * *}$ \\
\hline & $(0.057)$ & $(0.067)$ & $(0.051)$ & $(0.039)$ \\
\hline \multirow[t]{2}{*}{$\begin{array}{l}\text { Effectiveness of People's Inspection } \\
\text { Boards }\end{array}$} & $-0.090^{*}$ & -0.025 & $-0.191^{* * *}$ & $-0.107^{* * *}$ \\
\hline & $(0.053)$ & $(0.046)$ & $(0.044)$ & $(0.035)$ \\
\hline \multirow{3}{*}{$\begin{array}{l}\text { Unwillingness to report corruption } \\
\text { cases }\end{array}$} & & & & \\
\hline & $0.046^{* * *}$ & $0.056^{* * *}$ & $0.045^{\star * *}$ & $0.054^{* * *}$ \\
\hline & $(0.008)$ & $(0.009)$ & $(0.008)$ & $(0.006)$ \\
\hline \multirow[t]{2}{*}{$\begin{array}{l}\text { Seriousness of local governments in } \\
\text { dealing with corruption }\end{array}$} & $-0.645^{* * *}$ & $-0.726^{* * *}$ & $-0.679^{* * *}$ & $-0.434^{* * *}$ \\
\hline & $(0.055)$ & $(0.057)$ & $(0.040)$ & $(0.038)$ \\
\hline \multicolumn{5}{|l|}{ Demographic variables } \\
\hline \multirow[t]{2}{*}{ Gender } & 0.05 & -0.019 & 0.060 & $0.115^{* * *}$ \\
\hline & $(0.056)$ & $(0.056)$ & $(0.046)$ & $(0.037)$ \\
\hline \multirow[t]{2}{*}{ Age } & -0.003 & -0.001 & -0.002 & $-0.006^{* * *}$ \\
\hline & $(0.003)$ & $(0.003)$ & $(0.002)$ & $(0.002)$ \\
\hline \multirow[t]{2}{*}{ Length of permanent residency } & 0.000 & 0.002 & -0.001 & -0.002 \\
\hline & $(0.002)$ & $(0.002)$ & $(0.002)$ & $(0.001)$ \\
\hline \multirow[t]{2}{*}{ Ethnicity } & 0.011 & 0.027 & 0.091 & -0.002 \\
\hline & $(0.076)$ & $(0.105)$ & $(0.083)$ & $(0.060)$ \\
\hline \multirow[t]{2}{*}{ University education } & $-0.261^{* *}$ & -0.160 & $-0.325^{* *}$ & $0.192^{* *}$ \\
\hline & $(0.119)$ & $(0.141)$ & $(0.126)$ & $(0.083)$ \\
\hline \multirow[t]{2}{*}{ Secondary education } & 0.057 & 0.166 & -0.135 & -0.050 \\
\hline & $(0.150)$ & $(0.163)$ & $(0.139)$ & $(0.066)$ \\
\hline \multirow[t]{2}{*}{ Family size } & -0.015 & $-0.032^{*}$ & -0.004 & 0.015 \\
\hline & $(0.016)$ & (0.018) & $(0.013)$ & $(0.009)$ \\
\hline
\end{tabular}




\begin{tabular}{|c|c|c|c|c|}
\hline \multirow{2}{*}{$\begin{array}{l}\text { Dependent variable: } \\
\text { Overall corruption perception }\end{array}$} & \multicolumn{4}{|c|}{ Years } \\
\hline & 2011 & 2012 & 2013 & 2014 \\
\hline \multirow[t]{2}{*}{ Unskilled profession } & -0.089 & 0.046 & 0.067 & -0.044 \\
\hline & $(0.061)$ & $(0.078)$ & $(0.065)$ & $(0.047)$ \\
\hline \multirow[t]{2}{*}{ Skilled profession } & $-0.168^{* *}$ & -0.027 & 0.067 & 0.030 \\
\hline & $(0.083)$ & $(0.083)$ & $(0.078)$ & $(0.056)$ \\
\hline \multirow[t]{2}{*}{ Business owner } & -0.058 & 0.051 & $0.172^{\star *}$ & 0.054 \\
\hline & $(0.106)$ & $(0.102)$ & $(0.087)$ & $(0.062)$ \\
\hline \multirow[t]{2}{*}{ Household head } & -0.023 & 0.013 & 0.025 & -0.008 \\
\hline & $(0.064)$ & $(0.059)$ & $(0.045)$ & $(0.039)$ \\
\hline \multirow[t]{2}{*}{ Normal economic condition } & $-0.147^{*}$ & -0.063 & -0.078 & $-0.203^{* * *}$ \\
\hline & $(0.087)$ & $(0.088)$ & $(0.068)$ & $(0.060)$ \\
\hline \multirow[t]{2}{*}{ Good economic condition } & $-0.194^{* *}$ & -0.160 & -0.078 & $-0.203^{* * *}$ \\
\hline & $(0.094)$ & $(0.110)$ & $(0.085)$ & $(0.068)$ \\
\hline \multicolumn{5}{|c|}{ Variables controlling for selection bias } \\
\hline \multirow[t]{2}{*}{ University education } & $0.534^{* * *}$ & $0.642^{* * *}$ & $0.563^{* * *}$ & $0.365^{* * *}$ \\
\hline & $(0.052)$ & $(0.060)$ & $(0.064)$ & $(0.059)$ \\
\hline \multirow[t]{2}{*}{ High school } & $0.623^{* * *}$ & $0.764^{* * *}$ & $0.577^{* * *}$ & $0.339^{* * *}$ \\
\hline & $(0.071)$ & $(0.076)$ & $(0.080)$ & $(0.034)$ \\
\hline \multirow[t]{2}{*}{ Attention to news } & $0.272^{* * *}$ & $0.229^{* * *}$ & $0.247^{* * *}$ & $0.163^{* * *}$ \\
\hline & $(0.033)$ & $(0.031)$ & $(0.029)$ & $(0.029)$ \\
\hline \multirow[t]{2}{*}{ Member of a mass organization } & $0.302^{* * *}$ & $0.371^{* * *}$ & $0.350^{* * *}$ & $0.212^{* * *}$ \\
\hline & $(0.036)$ & $(0.037)$ & $(0.036)$ & $(0.027)$ \\
\hline \multirow[t]{2}{*}{ Former public servant } & $0.516^{* * *}$ & $0.356^{* * *}$ & $0.458^{* * *}$ & $0.270^{* * *}$ \\
\hline & $(0.068)$ & $(0.070)$ & $(0.083)$ & $(0.079)$ \\
\hline Provincial-specific effect & Yes & Yes & Yes & Yes \\
\hline Number of observations & 9,536 & 9,518 & 9,202 & 10,769 \\
\hline Uncensored observations & 2,175 & 2,257 & 3,145 & 4,951 \\
\hline Censored observations & 7,361 & 7,261 & 6,057 & 5,818 \\
\hline Rho & 0.022 & -0.078 & -0.078 & -0.079 \\
\hline Wald test of independent equations & 0.875 & 0.568 & 0.498 & 0.496 \\
\hline
\end{tabular}

Notes: Standard errors are in parentheses and robust to the cross sectional dependence within districts. ${ }^{* * *} p<0.01,{ }^{* *} p<0.05,{ }^{*} p<0.1$. 
Table 2: Variable description and source of data in PAPI

\begin{tabular}{llll}
\hline No Variable's name & $\begin{array}{l}\text { Level of } \\
\text { data }\end{array}$ & Type of data & Description \\
\hline
\end{tabular}

\section{QUESTION 1}

1 Overall corruption perception Individual

Scale from 0-6, the greater the more corruption

2 Voting in local election

Commune budget and expenditure disclosure

4

Effectiveness of People's Inspection Boards

Unwillingness to report corruption $^{b}$

Seriousness of local

6 governments in dealing with corruption cases

Scale from 1-10, willingness to report corruption
Overall corruption perception, an additive number in the six specific measures of corruption practices, i.e. diversion of state budget, bribes for land titles, bribes for health care, bribes for primary education, bribes for construction permit, and bribes for state employment.

Whether citizens come to vote personally in local elections of village heads or residential area heads

Whether commune/ward budget revenue and expenditures were publicized

The extent to which People's Inspection Boards function effectively

whereas higher values The amount of bribe to which citizens do not mind reflect lower filing a denunciation to responsible government authorities

Whether provincial governments are serious about dealing with corruption cases 
Individual

Yes (1), No (0)

\section{Gender}

Age

10 Living experience

11 Ethnic

12 University education

13 High school

14 Family size

15 Unskilled profession

16 Skilled profession

17 Business owner

18 Household's head

19 Normal economic condition

20 Good economic condition

21 Provincial-specific effect

\section{Question 1 (controlling for selection bias)}

Attention to news

Member of mass organization

Former public servant
Individual

Individual

$$
\begin{array}{cc}
\text { Individual } & \text { Yes (1), No (0) } \\
\text { Individual } & \text { Positive integers } \\
\text { Individual } & \text { Positive integers } \\
\text { Individual } & \text { Yes (1), No (0) } \\
\text { Individual } & \text { Yes (1), No (0) } \\
\text { Individual } & \text { Yes (1), No (0) } \\
\text { Individual } & \text { Positive integers } \\
\text { Individual } & \text { Yes (1), No (0) } \\
\text { Individual } & \text { Yes (1), No (0) } \\
\text { Individual } & \text { Yes (1), No (0) } \\
\text { Individual } & \text { Yes (1), No (0) } \\
\text { Individual } & \text { Yes (1), No (0) } \\
\text { Individual } & \text { Yes (1), No (0) } \\
\text { Province } & \text { Yes (1), No (0) }
\end{array}
$$

Individual
Yes (1), No (0)

Yes (1), No (0)

Yes (1), No (0)
Corruption perception in the six specific areas of the state budget, land title, health care, primary education, construction permit, and the public job recruitment.

Citizen's gender

A001

Citizen's age

A002

Citizen's living experience in the commune/ward

$\mathrm{A} 003$

Citizen's ethnicity: Kinh versus others

Citizen's education at university level and above

A005

Citizen's education at high school level

A006

Total members in the family

A006

A007

Profession of the household head

A010a

Profession of the household head

A010a

Profession of the household head

A010a

Whether the respondent is the household head

Today's economic condition of the family

A011

Today's economic condition of the family

A011

Province-specific effects of 63 provinces

Attention to national affairs and government

Current membership of mass organizations

A016

Former or current cadre or civil servant in the People's Committee 


\section{QUESTION 2}

22 Averaged quality of health care

District

Averaged percentage

23 Averaged quality of primary education

District

Averaged percentage

Averaged, scale from 0 to 2, the greater the more corruption

Averaged, scale from 0 to 2 , the greater the more corruption

primary education

District

District

District

District

28 Having national electricity

29 Paved or concrete roads

District

30 Tap water supply

Aggregated percentage

Aggregated percentage

Aggregated percentage

Aggregated percentage

Aggregated
This is an averaged figure of the ratios valuing good quality of health care, at public district hospitals, in various aspects

This is an averaged figure of the ratios valuing good quality of primary education, at public primary D606cd schools in the commune/ward, in various aspects

Corruption perception in the specific area of health care

D402c

Corruption perception in the specific area of primary education

D402d

Rates of poor households

Rates of people having health insurance

D601

Rate of households having electricity in the house

D607

Quality of the roads closest to the house

D608

Rate of household having tap water supply 